\title{
Fontes de pesquisa em Cabo Verde: o caso da Revolta dos Rendeiros no interior de Santiago (1822-1841)
}

Eduardo Adilson Camilo Pereira ${ }^{1}$

\begin{abstract}
Resumo: Este artigo pretende analisar e compreender tanto a relação de poder quanto os instrumentos legais de reivindicação contra as injustiças sociais no interior da ilha de Santiago, entre 1822 e 1841. Para tal, pretende analisar os requerimentos e os ofícios recebidos e dirigidos pelo governo geral de Cabo Verde, colectados no Arquivo Histórico Nacional de Cabo Verde, na cidade da Praia, no Arquivo Histórico Ultramarino e no Arquivo Histórico Militar, ambos em Lisboa.

Por outro lado, propõe analisar em que medida esses instrumentos administrativos refletiam a estrutura de poder vigente tanto no regime do governo geral quanto durante a vigência da prefeitura. Além disso, pretende compreender de que forma essas fontes permitem analisar os problemas sociais vigentes.
\end{abstract}

Palavras chave: Cabo Verde; Relação de poder; Reivindicações sóciopolíticas;

Abstract: This article aims to analyze and understand both the relationship of power and the claim of legal instruments against social injustice within the island of Santiago, between 1822 and 1841. To this end, it intends to analyze the requirements and documents received and directed by the general government Cape Verde, collected in the National Historical Archive Cape Verde in Praia, the National Historical Overseas Archive and Military Historical Archive, both in Lisbon.

On the other hand, aims to analyze to what extent these administrative instruments reflected the prevailing power structure both in the general government regime and during the life of the city hall. It also aims to understand how these sources allow us to analyze the current social problems.

Keywords: Cape Verde; Power relationship; Sociopolitical claims;

1 Professor Doutor no Instituto Superior de Ciências Jurídicas e Sociais, Praia - Cabo Verde. Email: eduardo_camilo7@hotmail.com 
Para Jean Chesneaux, as comemorações, os aniversários e os acontecimentos nacionais são parte de um conjunto de estratégias utilizadas pelo aparelho estatal para ritualizar o passado, colocando-o ao serviço da memória coletiva. A escolha de determinadas fontes não é ato do acaso, tendo em vista que possibilita a legitimação histórica do poder político. O que relembrar e o que remeter ao esquecimento estão intimamente ligados aos interesses daqueles que detém o poder, que procuram manipular a memória coletiva. ${ }^{2}$ Para tal, o aparelho do estado utiliza-se do sigilo, da destruição, da ocultação e do silenciosamente de arquivos embaraçosos para os interesses do grupo dominante. Além disso, podem também ser compreendidas como estratégias utilizadas para a reivindicação do passado, pois além de fomentar as lutas sociais, também é alvo de luta pela imposição de uma visão legítima do mundo social. ${ }^{3}$

Segundo Enrique Florescano, os arquivos revelam os interesses daqueles que decidem e governam, necessária para a legitimação da ordem estabelecida. Segundo este professor, a reconstrução do passado se apresenta como um dos principais instrumentos não só de legitimação da dominação de uns sobre os outros, como também para reivindicar o direito de dirigir o próprio destino. ${ }^{4}$ Cabe ainda ressaltar que a história possibilita não só a coesão da comunidade, enquanto pensamento integrador, ${ }^{5}$ como também um saber libertador e revolucionário. ${ }^{6}$

Para Terry Cook e Joan Schwartz, torna-se fundamental compreender as relações entre os arquivos e a sociedade que os criou, mediante o poder não só de fazer certos registos, como também de preservá-los. Defendem ainda que os arquivos não são lugares passivos e sim, lugares ativos, onde o poder social é negociado, contestado e confirmado. O seu poder não é neutro, mas aberto a debate vital. Não deixam de destacar o poder dos arquivos sobre a construção da memória

2 Para Michael Pollack, tanto os indivíduos quanto os grupos têm consciência da imagem de si, a imagem que ela constrói e apresenta aos outros e para si própria e o que possibilita ser percebida de maneira como quer ser percebida pelos outros - POLLAK, Michael. "Memória e identidade social”. In: Estudos Históricos. Rio de Janeiro, vol. 5, n. 10, 1992, p. 200-212.

3 CHESNEAUX, Jean. Devemos fazer tábula rasa do passado? (sobre a história e os historiadores). São Paulo: Ática, 1995 (Série Fundamentos, 109), p. 30-39.

4 FLORESCANO, Enrique. "De la memoria del poder a la historia como explicación". In: PEREYRA, Carlos et. al. Historia, para quê?. $17^{\mathrm{a}}$ ed., México: Siglo Veintiuno Editores, 1998. [1 ${ }^{\mathrm{a}}$ Ed. 1980], p. 91-128.

5 VILLORO, Luis. "El sentido de la Historia". In: In: PEREYRA, Carlos et. al. Historia, para quê?. 17a ed., México: Siglo Veintiuno Editores, 1998. [1ª Ed. 1980], p. 33-52.

6 GONZÁLEZ, Luis. "De la multiple utilización de la Historia". In: PEREYRA, Carlos et. al. Historia, para quê? $17^{\mathrm{a}}$ ed., México: Siglo Veintiuno Editores, 1998. [1ª Ed. 1980], p. 53-74. 
coletiva. $^{7}$

Já para Luciana Duranti, ${ }^{8}$ devemos ter em consideração que os documentos são criados no âmbito de um contexto administrativo determinado. Foram criados dentro de um sistema jurídico, pelo que os termos devem corresponder ao que outorga o contexto administrativo-jurídico. Além disso, cabe ressaltar que as organizações são culturas vivas ou organismos que criam e usam informações ${ }^{9}$.

O Arquivo Histórico de Cabo Verde apresenta grande variedade tanto de correspondências enviadas pelas autoridades quanto dos requerimentos dirigidos às autoridades, organizadas por destinatário ou remetente. Em relação ao primeiro, vêm acompanhadas da legislação, no cumprimento do dever por parte das autoridades, estruturam-se segundo a dispersão das ilhas e consoante às atribuições legais. Quanto ao segundo, revestem-se de solicitações ou pedidos feitos por particulares diretamente ao governo geral de Cabo Verde, o que atesta que, boa parte da população, não acreditava nos poderes locais, manipulados pelos morgados. ${ }^{10}$ Esse conjunto também realça a vivência cotidiana, os vexames, bem como o exercício do poder na esfera das freguesias.

Dentre essas duas fontes, propomos a análise dos requerimentos sobre as revoltas dos Engenhos (1822) e de Achada Falcão (1841). Tais reivindicações atestam os vexames, as denúncias de explorações, as confrontações políticas várias, bem como o próprio poder organizativo dos rendeiros ${ }^{11}$ em torno das ideias da tentativa de independência de Cabo Verde do império colonial

7 SCHWARTZ, Joan M. e COOK, Terry. Archives, records, and power: the making of modern memory. Archival Science, Dordrecht, v. 2, n. 1-2, p. 1-19, 2002.

8 DURANTI, Luciana. "La diplomática: disciplina fornativa y método de investigación". Diplomática: usos nuevos para una antigua ciencia. Traducción de Manuel Vázquez. Carmona: S\&C Ediciones, p. 143-166, 1996, p. 149.

9 BEARMAN, David A. \& LYTLE, Richard H.. The power of the principle of provenance. In: JIMERSON, Randall C., ed.. American archival Studies: readings on theory and pratice. Chicago: The Society of American Archivists, 2000, p. 345-360.

10 Grandes proprietários de terras, políticos, vigários da igreja católica e coronéis da infantaria colonial em Cabo Verde.

11 Rendeiros eram aqueles que arrendavam pequenas ou grandes dimensões de terras ao Morgado (a grande maioria) ou ao proprietário das mesmas, mediante um contrato feito na forma oral e sem nenhuma garantia, sujeitando-se aos caprichos do Morgado, que o podia expulsar quando bem quisesse. Parceiros eram os que se associam aos rendeiros, trabalhando a terra à custa do seu trabalho, dos familiares ou quer ainda pela entreajuda no seio da comunidade (djunta mon). Possuíam insignificantes parcelas de terras e praticavam essencialmente uma agricultura 
português.

Quanto à documentação sobre a posse da terra contém importantes informações sobre a disputa pela posse da terra no interior da ilha de Santiago. Durante décadas as revoltas dos rendeiros da ribeira dos Engenhos (1822) e de Achada Falcão (1841) têm sido compreendidas como sendo uma simples desordem registada, decorrentes do aumento arbitrário do arrendamento de terras, da proibição do tráfico de escravos, das fomes e secas, bem como dos desmandos desses proprietários de terras. Quanto aos estudos mais recentes, cabe destacar as de: Christianno José Senna Barcellos $^{12}$, Ilídio do Amaral ${ }^{13}$, António Carreira ${ }^{14}$, Cláudio Alves Furtado ${ }^{15}$, Elisa Silva Andrade ${ }^{16}$ e António Leão Correia e Silva. ${ }^{17}$ Além disso, limita-se a corroborar as hipóteses levantadas pela Coroa portuguesa, segundo as quais as revoltas dos rendeiros deviam-se tanto à má interpretação da Carta constitucional portuguesa quanto às maquinações de pessoas desafetos aos portugueses.

Já em relação a documentação sobre as decisões judiciárias, cabe destacar os autos da devassa sobre as revoltas dos Engenhos (1822) e de Achada Falcão (1841). As conclusões dos autos da devassa, mandada instaurar pelo Ministério da Marinha e Ultramar, contradizem os testemunhos prestados pelos rendeiros nos autos da devassa. Os pedidos dirigidos pelos rendeiros às autoridades coloniais, que fazem parte da série do Arquivo Histórico Nacional de Cabo Verde, permitem sustentar que as revoltas eram partes integrantes do projeto de emancipação de Cabo Verde em relação ao império colonial português. A utilização dessas fontes permite inviabilizar a ideia presente no programa de Ensino de História ( $12^{\circ}$ ano), segundo a qual as revoltas deviam-se tanto ao desespero quanto à insurreição dos rendeiros. Em segundo lugar, possibilita desfazer o estereótipo, segundo o qual os rendeiros seriam incapazes de autogovernarem-se. Em terceiro lugar, de subsistência.

12 BARCELLOS, Christianno José Senna. Subsídios para a História de Cabo Verde e Guiné. Lisboa, 1899-1911, parte IV, v. I, p. 279.

13 AMARAL, Ilídio do, Santiago de Cabo Verde: A Terra e os Homens. Lisboa: Memórias da Junta de Investigação do Ultramar, n. 18, 1964.

14 CARREIRA, António. Cabo Verde: Formação e Extinção de uma sociedade escravocrata (1460-1878). Porto: Imprensa portuguesa, 1972.

15 FURTADO, Cláudio Alves. Transformação das Estruturas Agrárias numa Sociedade em mudança - Santiago Cabo Verde. 357 f. Dissertação (Mestrado em Sociologia) - Faculdade de Filosofia, Letras e Ciências Humanas, Universidade de São Paulo. São Paulo, 1988.

16 ANDRADE, Elisa Silva. As Ilhas de Cabo Verde: da Descoberta à Independência Nacional (1460-1975). Paris: Éditions L'Harmattan, 1996, p. 115.

17 SILVA, António Leão Correia e. "A Sociedade Agrária: Gente das Águas (Senhores, Escravos e Forros)". In: ALBUQUERQUE, Luís de e SANTOS, Maria Emília Madeira (Coord.). História Geral de Cabo Verde. Lisboa: Centro de Estudos de História e Cartografia Antiga, Instituto de Investigação Científica Tropical; Praia: Instituto Nacional da Cultura de Cabo Verde, 1995, v. II, p. 275-359. 
demonstram que as revoltas eram decorrentes do projeto de revolução política para a independência do arquipélago.

Por um lado, esses instrumentos de reivindicação de direitos atestam não só a natureza das festas populares, como também as formas de mobilizações postas em prática na eclosão das revoltas. Atestam ainda que era costume fazer-se uso de manducos $^{18}$ ou paus para reagir contra qualquer injustiça. No caso da revolta dos Engenhos, os rendeiros, além de reforçarem a vigilância da ribeira, também fizeram uso de manducos contra todos aqueles que decidissem descer a ribeira sem a sua permissão. A referida revolta caracterizou-se pelo seu poder organizativo e, sobretudo, de resistência. Por meio de reuniões secretas, os rendeiros pretendiam impedir que o morgado cobrasse as rendas em atraso e, consequentemente, tomasse suas terras de forma despótica, para entregar a outro rendeiro, como foi o caso de Luiz Morreira, tenente dos Portos, fato comum até o momento da emergência da revolta. Nesse caso, os dois visados foram Zacarias Lopes e Valentim Varella, ambos tendo rendas em atraso. O requerimento dirigido ao governo geral ainda atesta que para fazer reunir os rendeiros, os convocadores utilizaram tanto da arma de fogo quanto do tambor tocado nos reinados das tabancas.

(...) algumas peçoas sem suspeita me diçeram [Manoel Carvalho Silva de Landim] q.e alguns dias tinhão constituído o numero de huns poucos de homens no citio de Pedra [dentro da ribeira dos Engenhos] e que no pr. ${ }^{\circ}$ dia erão mais de vinte e nos outros dias não eram tantos; e de noite fazia major numero de falando eu com os mesmos deserão-me q. tudo q.to tinha q. dizer sobre o ajuntam.to q. ia tenha escrevido o Morgado, e falando eu com o dito Zacarias q. se devia renda disse-me q. (...) o Morgado mandou publicar no dia primeiro de janeiro q. todos foçem pagar as rendas tanto velho como novas, e q. em Santiago reçebia todos os gêneros da terra; E também que pertendia fazer rendas em porçones grandes e q. suspeitarão elles q. Luis Morr. . Tomava alguma parte q. elles ocupa e por isso armarão $\mathrm{p}^{\mathrm{a}}$. impedir o Morgado no dia q. havia de hir fazer entrega a Luiz Morr ${ }^{\mathrm{a}}$; E tambem q. o Morgado tinha mandado dizer q. o Zacarias Lopes e Valentim Varella não erã mais seus rendeiros (...) Tenho maiz a enformar a V. Ex ${ }^{a}$. Q. estando eu a dormir no citio de Covão Grde. Algumas peçoas que comigo se achava me deçera q. pouco maiz ou menos seria doze oras da noite hum tiro e depois tocando tamboro parando no citio ahonde me achava a dormir paçando para cima; so o q. digo a V. Ex ${ }^{\text {a }}$. Q não sei (...) ate q. possa fazer temerei he o quanto poço $(. . .)^{19}$

Ainda possibitam-nos indagar sobre as formas e os rituais religiosos presentes nas

18 Pau feito de ramos de árvores e que era utilizado para debulhar o milho. Recorrentemente os rendeiros utilizavam os mesmos para defenderem dos abusos e violências dos seus morgados.

19 AHN, $S G G$, Requerimentos por ordem alfabética (a, c, d, f, j, n) - jan-jun/1822. Originais manuscritos. Cx. 27 (M). 
mobilizações populares contra a exploração. Atestam que muitos suspeitavam que os convocadores das reuniões andassem não só na ribeira dos Engenhos como também na ribeira da Boa Entrada. O número de rendeiros reunidos preocupou o proprietário de terra que desconfiado apelou para a rapidez judicial na prisão dos suspeitos e na eliminação do mal-estar causado pela presença dos incitadores. ${ }^{20}$ Porém, a dita presença não diminuiu de forma alguma as reuniões. As diversas solicitações encaminhadas ao governo geral demonstram que o proprietário detinha o poder de influência sobre a justiça local, e isso fez com que fossem destacados unicamente fatores de ordem econômica, em detrimento de fatores socais. Os incitadores das reuniões serviram de bode espiatório para a justiça. Dessas reuniões podemos destacar dois aspectos importantes. O primeiro aspecto se refere a participação de rendeiros de vários morgadios na revolta dos Engenhos. O segundo aspecto, possibilitando compreender que, à semelhança da celebração das festas de Corpo de Deus que agregava devotos provinientes de vários pontos do interior da ilha de Santiago, a revolta dos Engenhos congregou devotos e partidários de vários morgadios. Estes fatos possibilitam-nos compreender as razões pelas quais a junta governativa considerou a revolta como um mau exemplo para os outros morgadios, devido a resistência contra os oficiais de justiça. Além disso, a leitura desse documento permite sustentar que os rendeiros revoltosos, por meio de reuniões sigilosas nos limites do referido morgadio, fizeram acordos políticos com os liberais exaltados ${ }^{21}$ sobre a forma em que deveria se revestir os protestos contra os sucessivos abusos do proprietário de terra. Não obstante, os autos da devassa sobre a revolta dos Engenhos designa-a como sendo uma reunião dos rendeiros. Cabe ainda ressaltar que a estrutura administrativa presente nesses documentos referentes aos anos de 1822 e 1823 difere dos anos posteriores, uma vez que se poderia recorrer diretamente a esse poder público, sem a intermediação das administrações locais.

De um lado, tais documentos também nos ajudam a compreender não só as mentalidades, como também a percepção dos mesmos sobre a exploração que vinham sofrendo. O temor de que o morgado confiscasse as suas terras fez com que os rendeiros mobilizassem a volta de ideais políticos, visando impedir tais arbitrariedades. Possibilita-nos compreender em que medida esses políticos, fazendo acreditar que o mesmo pretendia confiscar as terras de todos os rendeiros que estivessem com rendas em atraso, conseguiram uma adesão cada vez maior por parte dos demais rendeiros. Para impedir tal arbitrariedade, estes últimos deveriam organizar-se para impedir que este, à margem da Constituição, continuasse a expulsar de suas terras os rendeiros devedores, na

20 AHN, $S G G$, Requerimentos por ordem alfabética (a, c, d, f, j, n) - jan-jun/1822. Originais manuscritos. Cx. 27 (M).

21 Grupo de políticos em Cabo Verde, liderado por Manoel António Martins, que reivindicava profundas reformas políticas, inclusive a separação das ilhas de Cabo Verde em relação a Coroa portuguesa em 1822. 
certeza que, agindo dessa forma, estariam a restabelecer a legalidade sucessivamente violada pelo morgado. As autoridades locais consideraram tal ato como medonho, uma vez que a liderança local tinha-se posicionado pela independência em relação à Coroa portuguesa. A revolta teve lugar no mês de janeiro de 1822, período em que normalmente os proprietários definiam como sendo o momento para que os seus rendeiros pagassem as rendas.

Por outro lado, a análise detalhada das solicitações dirigidas ao governo geral permite ainda compreender as diversas formas de resistências postas em prática. A revolta dos rendeiros estava, em parte, articulada à liderança local, composta por rendeiros que detinham um grande poder de influência sobre os demais. Foi assim que em 12 de fevereiro de 1824, Luiz Royer, administrador da fazenda de Faveta, na freguesia dos Picos, queixou-se ao então governador geral de Cabo Verde, João da Matta Chapuzet, que o seu rendeiro de nome Manoel Gonçalves tinha estado a fazer maquinações com outros rendeiros para que se revoltassem contra ele e então não pagariam as rendas estipuladas. Quando o administrador foi à casa do referido rendeiro para receber as rendas em atraso, este não só não consentiu sua entrada nas terras como buscou o seu manduco para espancar o cobrador. Por sua parte, o administrador agarrou a mulher do referido rendeiro para se proteger da tentativa de agressão do referido rendeiro. Por deliberação do governador-geral, verificou-se que o rendeiro em causa não devia rendas em atraso e que o administrador foi tentar tomar buracheiras ${ }^{22}$ ao pobre rendeiro. $\mathrm{O}$ fato do requerimento fazer referência às maquinações atesta a existência de mobilizações partidárias em torno do regime constitucional. ${ }^{23}$

Os autos judiciais se revestem de extrema importância para a compreensão do cotidiano das explorações, bem como a organização da revolta em si para resistir ao abuso do poder na esfera local. A força da rebelião acarretou, além da distribuição de sentinelas, a resistência aos mandados da justiça - "todos que para lá quizessem diregir, e ao mesmo tempo rezistindo os officiaes da execução que ali se achavão mandando dizer o Reprezentante que podia despedi-los, pois que não pertendião [pretendiam] mais pagar". ${ }^{24}$ Entretanto, passsado seis dias de cerco da casa do morgado, onde foram com intentos fúnebres, os rendeiros foram reunir armados de todas as qualidades de armas, sendo que aqueles que quisessem ir até a ribeira dos Engenhos, e tiveram de se dirigir ao quartel sendo, por vezes, presos por cerca de três dias ou ultrajados com palavras. Os oficiais de

22 Fabricação de borrachas.

23 AHN, $S G G$, Requerimentos: letras 1, p e s (1824). Originais manuscritos. Cx. 29.

24 AHM, Cabo Verde, Autos da Devassa a que se procedeu sobre o levantamento dos Habitantes da Ribeira do Engenho (1822-1823). 2a Divisão, $3^{\mathrm{a}}$ Secção, Cx. 2, Proc. 8. 
justiça, por colaborarem com o mesmo na cobrança violenta das rendas, eram vistos como pessoas sem alma, com poderes demoníacos e violaradores da lei de Deus. Os autos permitem atestar que os rendeiros não reconheciam a legitimidade das autoridades locais, resistindo às suas determinações de forma organizada, tendo em vista que a comunidade tinha as suas normas internas. Ademais, certifica que os rendeiros não reconheciam esse poder manipulado por aqueles poderosos.

A leitura dessas fontes auxilia na compreensão de que o pagamento das rendas assou a ser interpretado pelos rendeiros dos Engenhos como um ato político, uma vez que estes poderosos detinham também o poder político. Assim, muitas pessoas evitavam passar pela ribeira dos Engenhos, com medo de serem insultados e mesmo inquiridos sobre os motivos de sua ida àquela ribeira. Um exemplo pode ser dado pelo morgado Domingos Ramos Monteiro que não podia regressar àquela ribeira tendo em vista os abusos que vinha praticando. Os referidos trabalhadores rurais também negaram a entrada de oficiais de justiça portadores de mandados de prisão, o que em parte explicava a resistência. Isso porque o proprietário, por ocasião do vencimento das suas rendas, mandava-as cobrar, por meio de oficiais de justiça e seus criados, com toda a rigorosidade e violência. Não era por acaso que os rendeiros revoltados não permitiram a entrada de oficiais nas suas terras, já que eles eram tidos como coniventes com o roubo e as extorsões realizadas. A Junta Provisória do governo geral, que tinha se deslocado à freguesia de Santa Catarina a fim de prender os quatro indivíduos acusados, não pôde concretizar seu intento, por recear uma revolta dos rendeiros contra as autoridades locais. Segundo o mesmo ofício, tais indivíduos resistiram à prisão, reiterando não reconhecer a legitimidade da aludida prática. ${ }^{25}$ Os poucos trabalhadores que continuaram a pagar as suas rendas, fizeram-no em segredo, como foi o caso de Manoel Ramos que acabou sendo descoberto e então acusado, pelos outros, de traidor à causa coletiva ${ }^{26}$.

Ainda ajudam-nos a compreender o contexto da formação e da constituição do partido próBrasil, ${ }^{27}$ bem como as diversas formas de violência empregues contra os descontentes. Os movimentos contestatários na ribeira dos Engenhos e arredores deveriam ser compreendidos como a

25 AHN, $S G G$, Correspondências expedidas às diversas autoridades da ilha de Santiago (1822/ março/ 10-1823/ fevereiro/ 12). Cópias manuscritas. Livro 106, de 15 de março de 1822.

26 AHN, $S G G$, Requerimentos de Pessoas cujos nomes começam pelas letras b, c, d, e, f, g e h (1824). Originais manuscritos. Cx. 28, de 1 de abril de 1824.

27 Partido fundado por Manoel António Martins em 1822 na ilha da Boa Vista e que tinha como principal objetivo, reivindicar a autonomia de Cabo Verde em relação a Coroa portuguesa. Sabe-se que na ilha de Santiago, em 13 de janeiro de 1823, promoveu a recolha de assinaturas e o apoio dos soldados para não receber o novo governador enviado de Lisboa. 
manifestação da liberdade, contrária à opressão operada pelo despotismo. A revolta teve início, segundo os depoimentos prestados, quando o Domingos Ramos mandou derrubar a casa de um rendeiro que lhe devia dois anos de renda, com intuito de rearrendar suas terras. Também mandou prender o portador da carta que os demais trabalhadores tinham lhe enviado, reclamando dos sucessivos roubos praticados contra eles, segundo consta dos depoimentos de Manuel Francisco Coxo, ao desembargador ouvidor da província, de 23 de março de 1823 . Além do mais, o referido proprietário pretendia inibir os seus arrendatários de tal modo que estes não fossem à sua casa reclamar. Também era prática comum o morgado mandar colher os mantimentos daqueles que lhes deviam rendas. Para não padecerem, os mesmos decidiram fazer um ajuntamento como resposta aos sucessivos abusos cometidos. Segundo um dos depoimentos colhidos pelo desembargador ouvidor João Cardozo de Almeida Amado - “(...) huma mulher egualmente disse que Emcontrara em Caza de Andre Semedo, dado que passando pela Caza de Andre Semedo, vira muitos Rendeiros juntos Armados, e perguntando a Cauza daquelle ajuntamento elles lhe responderão que elle testemunha bem sabia (...)". ${ }^{28}$ A causa do ajuntamento não era novidade, uma vez que todas as reclamações eram dirigidas ao proprietário. Assim, fizeram cerco da casa do proprietário por sete dias consecutivos, retirando-se seguidamente para a região denominada Carreira. Estes fatos atestam que a casa de Andre Semedo foi utilizada para congregar e mobilizar os rendeiros, como se registava por ocasião dos cortejos da tabanca e dos reinados. Este rendeiro era um dos principais representantes dos liberais exaltados no interior da ilha de Santiago que, com a revolta, pretendiam reivindicar os direitos políticos negados pelo poder vigente. Tudo isso leva a crer que, em nenhum momento, é possível considerar a referida revolta como um acontecimento ocasional, mas sim, como fruto de mobilizações políticas planejadas, assentes em manifestações culturais próprias da ribeira dos Engenhos. Cabe ainda ressaltar que as festas religiosas representavam, para as autoridades civis e eclesiásticas, os principais momentos em que se procurava illudir ao publico, como também pôr em prática estratégias de mobilização dos vários grupos sociais.

As correspondências enviadas e recebidas pelo governo geral de Cabo Verde, no cumprimento das determinações régias, forma outro conjunto documental que poderemos encontrar na seção A, referente à administração geral. A leitura do ofício remetido pelo governo geral ao Ministério da Marinha e Ultramar, dando conta da apreensão da carta de uma das lideranças da revolta dos Engenhos, possibilitou compreender que a revolta, além de representar uma simples

28 AHN, SGG, Requerimentos de Pessoas cujos nomes começam pelas letras b, c, d, e, f, g e h (1824). Originais manuscritos. Cx. 28, de 1 de abril de 1824. 
reivindicação contra as imposições socioeconômicas, constituía uma oportunidade de subversão ao regime político vigente. Para tal, pretendia forçar as autoridades locais a reconhecerem os direitos políticos dos rendeiros, sobretudo o direito a posse das terras cultivadas. Outro indício do poder organizativo dos rendeiros à volta da revolta dos Engenhos é fornecido por outro documento, no qual o governador noticia que mesmo estando na cadeia, Manoel Francisco Coxo, continuava mantendo contato com algumas pessoas daquela ribeira. Este documento possibilita compreender a revolta enquanto mobilizações políticas à volta do partido separatista, bem como as estratégias políticas postas em práticas. Feita a apreensão das correspondências, o Ajudante de Milícias encarregado da missão encontrou um bilhete escrito a Manoel Ramos Semedo, no qual pedia que declarasse a revolução, pois do contrário, o governo geral de Cabo Verde não se responsabilizava pelos acontecimentos. Os autos da devassa sobre a constituição do referido partido, de 16 de maio de 1823, transcreveram uma Carta atribuída de Manoel Francisco Coxo a Manoel Ramos Semedo, onde não só reiterou o plano de não receber o governador vindo de Lisboa, como também que os responsáveis pela revolta nos Engenhos eram influentes políticos residentes na vila da Praia. A carta ainda aponta a existência do projeto revolucionário na ribeira dos Engenhos, destacando as alianças políticas com as elites locais.

Senhor Manoel Ramos Semedo não leve temor algum que por outras Couzas menos de que esta se prende hum homem quanto mais que não he nada assim. Logo que forem por Sua Excellençia lha declarem que Os Culpados são muitas pessoas desta Villa [Praia] Encradeinados [encarneirados] com os Outros sempre desta Ilha, os Crião empedir o dezembarque de Sua Excellençia e Logo que me esta outra esta para assim Vossa Merçe pedir torar alguma Couza digo pesoa se he verdade não quererem o nosso Governador por que se nos fazermos isto em Claro digo (...) se decidira da qualidade de nos Outros, e antão se vira no Conhecimento daquelles que sepraraceão para não aceitar o nosso Governador, Deos Meos de a Vossa Merçe muitos annos Seu Amigo Manoel Francisco de Sequeira. ${ }^{29}$

Dentre esses documentos, cabe destacar ainda os referentes à cobrança de dívidas, como também os que eram diretamente dirigidos pelos cidadãos ao governo geral, sem passar pela administração local. Apenas um requerimento dirigido pelo acusado ao governador geral de Cabo Verde, João da Matta Chapuzet, de 28 de julho de 1826 chegou ao nosso conhecimento. Neste documento pedia-se a cobrança de uma dívida de onze mil e seiscentos e setenta reis de Manoel Ramos, morador na ribeira dos Engenhos, pois este não cumpriu, como acertado, as determinações

29 AHU, Cabo Verde, Cx. 72, doc. 43, f. 22 e 23. 
da liderança partidária. O governador ainda autorizou, no mesmo documento, a sua transferência para a ilha do Maio. ${ }^{30}$ Note-se que o morgado queixou-se ao governo geral que os seus rendeiros estavam a exigir um conjunto de condições inaceitáveis. Além disso, a sua análise possibilita compreender os procedimentos administrativos. Das decisões deste que, na maioria dos casos, representava o poder administrativo local, cabia recurso ao governo geral.

(...) Tendo mandado proceder à prizão de Manuel Francisco de Sequeira o Coxo, por estar á testa dos levantados da Ribeira do Engenho, apelidando-se seu General, fui informado de que elle escrevia da prizão para algumas pessôas da Ribeira do Engenho, mandei por hum official da Tropa desta Guarnição, Vicente Jose das Neves, Ajudante de Milícias, aprehender-lhe todos os papeis, que tivesse em seu poder, e entre elles se encontrou hum bilhête escripto a Manoel Ramos Sêmedo, no qual lhe dizia, que declarasse a revolução, que se tinha intentado fazer, pois neste cazo olharião com indiferença para os acontecimentos, que tinhão havido na Ribeira do Engenho; mandei chamar o Ouvidor por bem da Ley, com dois escrivães, afim de autuarem os papeis encontrados ao ditto Manoel Francisco de Sequeira, e fazerem-se-lhe as perguntas, que fossem convenientes, cujos papeis vão ser remettidos a Vossa Senhoria juntamente com os outros, para servirem de esclarecimento á Devassa, que se deve tirar sobre os acontecimentos da Ribeira do Engenho (...). ${ }^{31}$

Comprovam também que a revolta dos Engenhos, além de uma mera contestação fundiária contra as arbitrariedades dos proprietários de terras, deve ser também compreendida como produto de mobilizações políticas. O próprio documento destaca a importância de se declarar a revolução política, em função da qual a revolta deverá ser compreendida. Segundo consta, as revoltas só seriam eficazes se acompanhadas de acontecimentos que marcassem o começo de profundas transformações políticas e sociais. A contestação fundiária só teria o resultado esperado se estivesse articulada à contestação política, tendo em vista que as arbitrariedades e o monopólio da terra estavam assentes no regime monárquico. O documento anuncia um conjunto de estratégias e práticas sociais que os rendeiros deveriam colocar em prática durante a revolta, por intermédio de práticas subversivas. $\mathrm{O}$ discurso presente na carta permite-nos articular essas práticas subversivas àquelas referentes à mobilização presente na revolta. Tal projeto, decorrente da aprovação da nova constituição, pressupunha a garantia de direitos e liberdades individuais. A carta atesta que os rendeiros reclamavam do aumento arbitrário das rendas das terras e dos vexames, ao mesmo tempo

30 AHN, $S G G$, Requerimentos dirigidos ao Governador da Província de Cabo Verde (1926). Originais manuscritos. Cx. 31.

31 AHU, Cabo Verde, Cx. 72/ doc. 44, de 16 de maio de 1823. 
em que exigiam o reconhecimento dos direitos políticos. Ainda atesta que a revolta deve ser compreendida, antes de tudo, como reivindicação pelo exercício dos direitos políticos decorrentes da mudança de regime político.

Por outro lado, comprovam que as autoridades locais viam com indiferença tanto as queixas individuais formuladas ao governo geral quanto às resistências ao pagamento das rendas. Atestam que a revolta só teria significado se articulada às mobilizações partidárias pela garantia dos direitos individuais a todos os rendeiros da ribeira dos Engenhos. Segundo os vários depoimentos, os rendeiros reivindicavam uma cidadania isenta de exclusões por rendas, instrução ou sexo. Também defendiam que a revolução seria instrumento eficaz para marcar o fim da escravidão, bem como introduzir mudanças de condições de vida nas camadas mais pobres e oprimidas. Todas essas mudanças só poderiam ser alcançadas por meio de mudanças profundas tanto na forma de governo quanto na organização política.

Os ofícios dirigidos pelo governo geral às administrações locais possibilitam compreender as expectativas dos rendeiros em torno não só da administração local, como também em relação ao governo geral. A existência do projeto revolucionário pode ser ainda atestada, por meio do ofício, de 27 de março de 1822, enviado pela junta do governo provisória de Cabo Verde a Dominico Furtado de Mendonça. Segundo este Domingos Ramos Monteiro, havia reportado que os líderes da revolta foram à casa de Joaquim Tavares e de uma mulher e que por estes não quererem ser do seu partido, lhe tinham morto um porco e roubado aguardente. ${ }^{32}$ Devemos ter presente que as mobilizações políticas são também reflexos de certa oferta política, assente nas relações entre oferta e procura. Este documento mostra que os rendeiros revoltosos iam à casa dos demais rendeiros, a fim de convocá-los a integrar o partido liberal, o único capaz de lhes garantir liberdade e a posse das terras cultivadas.

As solicitações ao governo geral ainda demonstram estruturas diferenciadas. Se inicialmente as reclamações eram feitas de forma individualizada, com a liderança partidária, os rendeiros passaram a propor não só linha de ação, como também as estratégias para debelar a cruel exploração que vinham sofrendo. Aproveitando das organizações comunitárias e religiosas, como a tabanca, os reinados e as irmandades, passaram a estabelecer laços de solidariedade também na luta partidária, compreendendo que vinham sendo roubados tanto pelos proprietários quanto pelas

32 AHN, SGG, Correspondências expedidas às diversas autoridades da ilha de Santiago (1822/março/101823/fevereiro/12). Cópias manuscritos. Livro n 106. 
autoridades coloniais. Segundo estes, as mobilizações partidárias só teriam êxito se fossem fundadas nas necessidades e aspirações dos rendeiros, como também na compreensão dos fundamentos culturais locais. A análise desses documentos demonstra que esses trabalhadores rurais e sua respectiva liderança reclamavam a posse legal das terras cultivadas. Além disso, os próprios objetivos do partido visavam unificar os sentimentos e as aspirações de todos os rendeiros explorados pelo regime despótico.

Embora os governadores gerais aceitassem dos rendeiros todas as reclamações por escrito contra os seus morgados. Na prática, essas solicitações individuais dos rendeiros não eram tidas em consideração pelo governo geral, tendo em vista que não eram relevantes para o regime político em vigor, que representava os interesses desses poderosos. Segundo Bourdieu, a existência de um grupo social pressupõe, além da distinção, ser reconhecido como sendo diferente tanto jurídico quanto politicamente ${ }^{33}$.

As referidas fontes atestam a influência que os referidos políticos detinham tanto sobre o governo geral quanto sobre o poder judicial. Era do interesse não só de Domingos Ramos Monteiro, influente proprietário e coronel, como também da junta governativa de Cabo Verde e da justiça local responsabilizar apenas quatro indivíduos pela revolta. São eles Lourenço Cabral, Pedro Semedo, Martinho Semedo e Lourenço Semedo, tendo à testa como general um Manoel Francisco de Siqueira, vulgarmente conhecido por Coxo. ${ }^{34}$ Por meio de um conjunto de exposições dirigidas a este poder público e ao juiz da Ribeira Grande, o referido proprietário, ao abrigo do seu direito como proprietário, exerceu pressão indireta sobre a decisão judicial, chegando mesmo a argumentar que os levantados faziam pressão direta sobre os que não queriam tomar parte da revolta. A decisão de este poder público fazia crer que a revolta era única e exclusivamente produto da vontade criminosa de alguns indivíduos descontentes com o sistema colonial português em Cabo Verde. Outro argumento utilizado consistiu em afirmar que os rendeiros e os respectivos indivíduos que os mobilizaram, interpretou de forma equivocada o princípio da liberdade trazido pela nova constituição, o que levou o governador João da Matta Chapuzet a pedir o perdão para os acusados, alegando que a Constituição os havia levado à alucinação. A análise da documentação dirigida tanto à administração local quanto ao governo geral, bem os depoimentos presentes nos autos permite sustentar que as mobilizações se deviam também aos descontentamentos populares.

33 BOURDIEU, Pierre. O poder simbólico. $11^{\mathrm{a}}$ ed., Rio de Janeiro: Bertrand Brasil, 2007 . [1 $1^{\mathrm{a}}$ ed. 1989], p. 129.

34 AHM, Cabo Verde, Autos da Devassa a que se procedeu sobre o levantamento dos Habitantes da Ribeira do Engenho (1822-1823). $2^{a}$ Divisão, $3^{a}$ Secção, Cx. 2, Proc. 8 
Por outra parte, as apelações dirigidas às instâncias judicais se revestem de tamanha importância não só para a compreensão dos procedimentos judiciais, como também do próprio poderio desses proprietários. A análise das suas solicitações às instâncias judiciais do arquipélago nas próprias correspondências oficiais do governo geral é indicativa do poder que estes detinham. Por meio de um desses procedimentos, Domingos Ramos, pediu ao juiz da cidade da Ribeira Grande a desocupação das terras e das respectivas casas dos rendeiros João Semedo da Fonseca, Pedro Semedo Cardozo, Martinho Semedo e de todos os herdeiros de Nocolao Lopes Tavares e Dona Brazia Semedo, entre os quais se destacam Paulo Semedo, capitão do Regimento de Melicias da Ribeira Grande. Também que obrigasse os referidos rendeiros a pagarem as rendas devidas, no valor de cento e vinte mil reis. Caso contrário, pedia a transferência dessa obrigação para os seus familiares e parentes. Ainda, no mesmo documento, de 23 de fevereiro de 1823, o mesmo estabeleceu um prazo de quinze dias para que os rendeiros, acima referidos, pagassem as rendas em atraso. Caso contrário, além de despejá-los, confiscaria todos os seus bens, segundo o montante das dívidas que constam nos seus registros. ${ }^{35}$ A leitura dessa fonte permite compreender a estrutura hierárquica do poder judicial. Das decisões da justiça camarária cabia recurso ao juiz de direito na Ribeira Grande, que detinha jurisdição sobre todo o arquipélago.

Outra importante fonte para a compreensão do cotidiano de exploração dos rendeiros são os ofícios dirigidos às autoridades religiosas pelo governo geral, importante instrumento na administração do arquipélago. Num oficio dirigido ao bispo de Cabo Verde, de 6 de maio de 1822, tomou-se conhecimento das reivindicações dos rendeiros contra o Coronel Domingos Ramos. Atesta ainda que esses trabalhadores rurais consideravam que as injustiças, decorrentes da exploração, eram legitimidas pelo governo geral. Segundo consta, "Esta Junta (...) tem procurado fazer entrar nos seus deveres os habitantes da Ribeira do Engenho no principio levantados, e queixosos contra daquellas terras o Coronel Domingos Ramos, e agora (...) dezobidientes a este Governo (...)".36

As referidas fontes ainda atestam que a inexistência de cartórios, registros e juízes nas câmaras municipais dificultava ainda mais as providências da justiça local para pôr cobrança aos desmandos dos morgados. Outras vezes, os funcionários, sob influência dos mesmos, faziam com que as reivindicações escritas dos rendeiros fossem destruídos ou simplesmente desapareciam. Nos

35 AHN, $S G G$, Requerimentos de Pessoas cujos nomes começam pelas letras b, c, d, e, f, g e h (1823-1824). Originais manuscritos. Cx. 28, de 23 de fevereiro de 1823.

36 AHN, $S G G$, Correspondências expedidas às diversas autoridades da ilha de Santiago (1822/ março/ 10-1823/ fevereiro/ 12). Cópias manuscritas. Livro 106. 
cartórios, as devassas gerais mandadas instaurar pelo ouvidor geral contra o despotismo e violências praticadas desapareciam com frequência. Assim, quando o ouvidor geral requisitava registros para fins de fiscalização e correção das câmaras, não encontrava nenhuma menção as reivindicações desses trabalhadores rurais. Por seu turno, estes, em sinal de protesto, recusavam a obedecer as determinações tanto de autoridades locais quanto do governo geral, alegando falta de interesse destes na solução dos casos. Às vezes congregavam para contrariar as determinações das autoridades administrativas e judiciais, desobedecendo e transgredindo as suas decisões. A legitimidade dos seus protestos advinha de costumes antigos, presente nas antigas legislações sobre a propriedade da terra, dentre os quais, os proprietários deveriam aproveitar as terras no prazo de cinco anos.

As correspondências enviadas às administrações atestam o temor desta diante do emprego da força, bem como as várias diligências feitas pelos padres locais para conter as revoltas dos rendeiros. Desde o começo das diligências para restaurar a ordem na ribeira dos Engenhos, as autoridades locais apresentaram-se receosos em aplicar a força para conter os rendeiros. Grande parte dos soldados da guarnição era parente direto dos rendeiros daquela ribeira e, consequentemente, "se lhes applicarmos a força temos, a temer a Guarnição desta Praça, porque huma parte della he filha, ou aparentada na mesma Ribeira (...) os quês vendo marchar armas contra seus Paes, podem tentar-se a voltar as suas armas contra nós e entrar mos em huma guerra Civil". ${ }^{37}$ Não por acaso, tenha decidido, unanimemente, que primeiro iria esgotar todas as formas de persuasão para, só em última instância, usar a força. Para tal, foi dirigido um ofício ao bispo de Cabo Verde, implorando para que disponibilizasse os padres mais influentes, a fim de convencer os rendeiros. Assim, para tal, foram designados o cônego Matheus Gonçalves Varella, vigário de Santa Catarina, Custodio Roiz Cabral e o Sargento-Mor Francisco de Barros de Oliveira. Sabe-se ainda que, após o recebimento de um ofício do bispo de Cabo Verde, datada de 10 de maio de 1822, a Junta de governo veio, por meio de outro ofício de 11 de maio de 1822, felicitar o mesmo pelas diligências no sentido de persuadir os rendeiros levantados. ${ }^{38}$

Essas fontes ainda ressaltam o grande prestígio social dos padres entre os devotos do interior da ilha de Santiago. Para este poder público, era preciso que os padres fossem pessoalmente à ribeira dos Engenhos para dirigir a palavra aos manifestantes, os quais detinham uma grande

37 AHU, Cabo Verde, Cx. 72/ doc. 32, de 20 de setembro de 1823, f. 21.

$38 \mathrm{AHN}, S G G$, Correspondências expedidas às diversas autoridades da ilha de Santiago (1822/ março/ 10-1823/ fevereiro/ 12). Cópias manuscritas. Livro 106. 
influência entre os devotos daquele morgadio. ${ }^{39}$ Segundo consta, os emissários deveriam dirigir-lhes palavras dóceis, usando mesmo valores como a caridade e a amizade, como também "fazer-lhes crer que esta junta está pronta, e dezeja ouvir as suas queixas para à vista dellas, e da resposta do Morgado fazer arbitrar huma renda fixa" ${ }^{40}$ A análise do discurso proferido pelo novo governador na região da Pinha dos Engenhos demonstra que o governo geral da província analisou a revolta como um ato isolado de alguns indivíduos enganados ou iludidos pela nova constituição.

As correspondências recebidas das administrações locais ajudam-nos a compreender a grande concentração de terras, alvo de diversas reivindicações da parte dos rendeiros. A fazenda de Achada Falcão pertenceu a Santa Casa de Misericórdia até 1829, momento em que Nicolau dos Reis da Fonseca Borges, juiz ouvidor geral de Cabo Verde e intendente da polícia em 1823, por meio de um requerimento, pediu a remissão de duas ou três fazendas, que a Santa Casa de Misericórdia tinha feito graça a diversas pessoas. ${ }^{41}$ Dentre as fazendas estava a de Achada Falcão, sem rendimento na produção das terras, tendo os rendeiros se recusado a pagarem qualquer imposto. Mas o suplicante juiz Nicolau dos Reis Borges só viria a receber esta graça no ano de 1829, tendo como principal missão a recuperação dos rendimentos da referida fazenda. ${ }^{42}$ É ainda importante salientar que o mesmo era dono de várias terras da ilha de Santiago. Note-se que a escritura de venda feita em 9 de julho de 1827 pelo cônego Simão Duarte Ferreira a Ambrósio Gomes de Carvalho das terras denominadas de Bica e Gallé, situadas na ribeira de São Francisco, atesta que Nicolau dos Reis foi o primeiro proprietário das mesmas. Ele era também proprietário das terras de Tanque de Nora, satisfazendo para isso todos os encargos financeiros com a fazenda pública. $^{43}$

O Arquivo Histórico Nacional de Cabo Verde contém uma série diversificada de requerimentos dirigidos pelos rendeiros ao governo geral que atestam o cotidiano de extrema exploração desses trabalhadores rurais. Por meio de um desses instrumentos legais dirigido ao governador da província, o rendeiro Manoel Gonçalves, denunciou o excesso das mesmas e as sucessivas ameaças de expulsão das terras que vinha sofrendo por parte do morgado. Pelos

39 AHN, $S G G$, Correspondências expedidas às diversas autoridades da ilha de Santiago (1822/ março/ 10-1823/ Fevereiro/ 12). Cópias manuscritas. Livro 106, de 6 de maio de 1822.

40 AHN, SGG, Correspondências expedidas às diversas autoridades da ilha de Santiago (1822/ março/ 10-1823/ fevereiro/ 12). Cópias manuscritas. Livro 106, de 6 de maio de 1822.

41 Infelizmente não dispomos da data precisa do requerimento.

42 AHN, $S G G$, Requerimentos sem entrada e data. Originais manuscritos. Cx. 27, s/d.

43 AHN, $S G G$, Correspondências recebidas das Administrações de diversos Concelhos do país (setembro 1842fevereiro 1844). Originais e cópias manuscritas. Cx. 122. 
documentos oficiais percebe-se que a denúncia é pertinente, uma vez que todo o trabalho inicial do cultivo da terra foi desenvolvido pelo referido suplicante, o qual viu todo o seu esforço menosprezado tanto pelo proprietário como pela câmara municipal de Santa Catarina. Assim,

(...) Diz Manoel Gonçalves morador na Boa Ventura desta Ilha, que avera dez annos que elle Supp.te arendou huma porção de mattas maninho, ao Capitão Mor Nicolau Dos Reis Borges por preço de quatro mil reis, onde cultivando o Supp.te fez plantios de regadio, e de saccos de simenteiras (...) E por que no expasso de tempos, o falecido Carlos Lopes, veio a rendar p.te das terras no dito Morgado, fez subir o Supp.te a renda em seis mil reis, a qual pagou a quantia dois annos; Falecendo pois o sobredito Loppes, o Menorista Manoel Tavares, como irmão da viuva do falecido se foi abrigar a mesma renda ao Morgado (...) o qual no anno próximo passado o Supp.te lhe pagou a sua renda de seis mil reis, preço em que o avia arbitrado a seu cunhado falecido; acontece purem que nos princípios do corrente mez de Junho indo o mençionado Menorista ao referido citio, fez crecimento das rendas, onde arbitrou o Supp.te em doze mil reis pagos annualmente, a cujo exorbitante preço aseitou p.r nao ter lugar em que pode-se recolher com a numeroza família q. tem, sendo alguns ali nascidos e criados; Ficando pois o Supp.te sujeito a pagar a quantia de doze mil reis, quando de repente lhe chega hua ordem avera seis dias do referido Tavares detriminando o Supp.te retirar-se das cazas e terras, no expassso de vinte quatro oras, sem nenhuma contemplação aos servissos, que tanto lhe custou o sangue de suas veias, e vendo-se o Supp.te no deplorável extado [estado] que aclama athe os Ceos, Se recorre ao patroçenio de V. Ex.ca e P. ao S. Ill.mo e Ex.mo Sem.r G.or G.el da Província, que tendo concideração ao asima annarrado, Se digne mandar p.r Seu Despacho, que Se conserve o Supp.te na Sua renda, p.r não ter onde recolher-çe com a sua famillia, que o contr. ${ }^{\circ}$ ficão ao Dezemparo. ${ }^{44}$

O fato de essa solicitação ser dirigida diretamente ao governador geral, reivindicando a proteção das autoridades locais, demonstra que das injustiças praticadas cabia recurso ao primeiro, que poderia determinar, unilateralmente, a sua suspensão. Como é possível verificar, esses trabalhadores rurais vinham sofrendo com as medidas arbitrárias do referido proprietário desde finais de 1828. Segundo consta, mesmo que pagasse suas rendas em dia o seu futuro estava diretamente associado ao desejo do morgado, o qual se encontrasse outros trabalhadores interessados no arrendamento das mesmas terras colocaria uma série de dificuldades ao detentor das terras. Uma das maneiras era aumentar arbitrariamente as rendas de ano em ano até o ponto do mesmo não poder mais honrar os pagamentos, o que gerava o seu endividamento que acabava sem ter como pagar as rendas em atraso, tendo suas terras serem confiscadas pelo morgado. Assim, a valorização das terras aumentava na medida em que surgissem novos pretendentes às mesmas. Tudo

$44 \mathrm{AHN}, S G G$, Requerimentos (janeiro-setembro/ 1828). Originais manuscritos. Cx. 33, de 25 de junho de 1828. 
isso criava no rendeiro uma incerteza quanto ao seu futuro, medo esse agravado pela inexistência de um contrato escrito, o que impossibilitava uma reclamação legal contra o morgado. Se dantes pagava quatro a seis mil reis pelo usufruto das terras, doravante vê o valor da renda ser duplicado para doze mil reis num espaço de três anos. Segundo a documentação consultada, o aumento da renda das terras era recorrente, principalmente quando os mesmos trabalhassem em parceria com outros familiares. Atestam que o principal intento do proprietário visava manter a dependência económica do rendeiro em relação a ele, já que ele representava uma grande ameaça para a ordem político-económica vigente. Quanto maior fosse à colheita obtida com o trabalho de parceria, maiores eram os valores das rendas reajustadas.

Esta fonte ainda atesta que os referidos trabalhadores, para não serem expulsos das terras, aceitavam qualquer imposição por parte dos proprietários de terras. Estes, almejando grandes lucros com o comércio, ignoravam todo o trabalho feito pelos rendeiros, determinantes para que a terra podesse se tornar produtiva. A leitura deste documento permitiu a esta pesquisa sustentar que esses poderosos aumentavam as rendas das terras como estratégia política para impedir que os seus rendeiros obtivessem lucros com a venda das colheitas. Esta denúncia mostra que o rendeiro reclamava das arbitrariedades do morgado, enquanto capitão mor do governo colonial português em Cabo Verde. Pela sua destacada posição social e política, detinha grande influência sobre a justiça local, a qual era conivente com as expulsões de rendeiros das terras cultivadas. Além disso, demonstram que, como as terras de regadio eram mais concorridas pelos rendeiros, os mesmos sobrevalorizavam as mesmas, com aumentos desproporcionais das rendas pagas pelos rendeiros.

A análise dessa fonte atesta ainda que os padres, além do poder religioso, também detinham grande poderio econômico. O menorista, ${ }^{45}$ padre Manoel Tavares, por meio de um dessas solicitações dirigidas ao juiz ordinário da Ribeira Grande, André Mendes d'Afonso, apresentou uma lista de rendeiros que estavam lhe devendo rendas das terras. No mesmo documento exigiu do juiz da comarca de sotavento ${ }^{46}$ a imediata execução da cobrança das rendas em atraso, punindo com expulsão das terras os que persistissem em não pagar as dívidas.

Ex.mo Sem.r Manoel Gonçalves. Em execução ao respeitável despacho de Vossa Ex. ${ }^{a}$ de 28 de Junho deste prezente anno Sou a Informar a V. Ex. ${ }^{a}$ que tendo me aprezentado o Padre Manoel Tavares hum requerem.to com hum rol em Cluzo [incluso] de varios rendeiros que lhe estavão devendo rendas

45 Clérigo de ordens menores.

46 Grupo das ilhas de Cabo Verde de leste para oeste: Maio, Santiago, Fogo e Brava. 
das terras (...) requeremdome no mesmo: mandacçe pasar modo p. ${ }^{\mathrm{a}}$ cobrança das mesmas rendas e que aquelles que fossem renetentes e prezestentes [persistentes] em não querer pagar o q cada hum Justa m.e [justamente] deve a q.e fossem espulços das terras que ocupava e achando eu justo o Seu requerimento assim o deferi Com o qual me reporto V. Ex. ${ }^{\mathrm{a}}(\ldots) .{ }^{47}$

A leitura das reivindicações dirigidas ao governo geral a vários rendeiros de Achada Falcão, interior da ilha de Santiago, possibilitou verificar que a revolta estava assente tanto nos princípios liberais, como também que a disparidade de rendas das terras afixadas estava articulada a propósitos políticos. Isso explica que a maioria dos intervenientes, para garantir as suas terras para futuras colheitas e não ficar à mercê de arbitrariedades, exigiu um contrato escrito de arrendamento das terras. Também os exaltados denunciaram que apenas meia dúzia de homens tinha a posse das terras mais férteis que, por sua vez, pertenciam às camaras municipais ${ }^{48}$.

Os requerimentos existentes no Arquivo Histórico Nacional de Cabo Verde atestam ainda o grande monopólio das terras, bem como a falta de execução das leis sobre a terra. A análise dessas fontes abre possibilidades para compreender a própria estrutura administrativa ali expressa, tendo em vista que os suplicantes dirigiam as suas reivindicações às administrações locais que, por sua vez, os submetiam à consideração do governo geral. Por meio deste recurso legal, os referidos trabalhadores rurais, com base na carta de lei de 20 de dezembro de 1837, passaram a exigir contratos por escrito que trouxessem o selo de quarenta reis, confirmando o registro do arrendamento feito. Exigiram ainda das autoridades, um documento formal que desse suporte e, principalmente, garantia contra as arbitrariedades dos proprietários de terras. Além disso, requereram uma cópia dos contratos, assim como a confirmação da lei de arrendamento em vigor.

Dizem Parte dos Moradores do Concelho de Santa Catarina desta Ilha de Santiago Província de Cabo Verde que pagão Rendas a Morgados os quais os supp.tes julgão que elles o não são pello que pação a expor ${ }^{a} \mathrm{~V}^{\mathrm{a}}{ }^{\mathrm{a}} \mathrm{Mag}$. ${ }^{\mathrm{a}}$ por esta Suprema Justiça o seguinte há apenas meia dúzia de homens que se achão de posse dos terrenos desta Ilha terrenos que a maior Parte pertencem as Câmaras Monocipais terrenos que he pressizo Comservvallos para Rosintos e Logradouros de gados terrenos que a Fazenda nasional pode tirar produto e os Povos não serem, já sacrificados como o são e tem sido (...)

Dizem Miguel Vorada.. Fran.co Xavier de Andrade...Portazio Martins... Andre domingo Géromono Gomes... Francisco Fernandes... e Jose Maria Tavares... todos do Concelho de Santa Catarina que elles Supp.es tem bens

47 AHN, $S G G$, Requerimentos (janeiro-setembro/ 1828). Originais manuscritos. Cx. 33, de 28 de junho de 1828.

48 AHN, $S G G$, Correspondência diversa recebida das diferentes Administrações de concelhos da Província de Cabo Verde (1841). Originais e cópias manuscritas. Cx. 122, de 24 de março de 1841. 
aRendados de Morgadios e paga o Primeiro Supp.te, 700 mil Reis em Xara (Achada) Falcão a Nicolao dos Reis... o Segundo Supp.e paga 6300 ao mesmo... O terceiro Supp.e paga de Renda 1800 reis ao mesmo(...) Quarto Supp.e paga de Renda de hum Lugar e orta 7400 reis, a Nicollao dos Reis... Quinto Giromono Gomes paga de Renda 3950 de hum Lugar em Xara Falcão a Nicollao dos Reis/... Sesto Fran.co Fernandes paga de Renda 1200 reis a Nicollao dos Reis de hum Lugar/ em Xara Falcão (...) porque nunca os Supp.tes tiverão Arrendamentos por Escrito, os quais os Senhorios dos terrenos devem dar, ate com o Sello de quarenta reis cada hum Arrendamentopor ser, utillidade Publica a Beneficio da Fazenda Nacional e Segorança para o Inclino. C. a V. ${ }^{\text {a }}$ Mag.e se Digne Mandar que de hoje em diante todos os Senhorios Sejão obrigados a darem a Rendamentos por Escrito a seus Inclinos [inquilinos] e sellados com o Sello que Marca a Lei de 20 de Dezembro de $1837 .{ }^{49}$

A análise dessas fontes atesta a tamanha revolta social presente entre os habitantes do interior de Santiago, bem como as assimetrias vigentes. Estes justificaram os seus pedidos com base em duas Cartas de lei recém aprovadas pela Coroa portuguesa. A primeira é a Carta de lei de 25 de junho de 1766, que previa o confisco dos bens pertencentes à Coroa, às Câmaras e aos Concelhos. Quanto a segunda Carta de lei, de 20 de dezembro de 1837, em vigor a partir de primeiro de janeiro de 1838, estabelecia que para a anexação de um morgado era indispensável o cumprimento das seguintes condições: ter quatro contos de reis de capital; cinquenta mil reis de selo, sendo que para todos os arrendamentos eram obrigatórios quarenta reis de selo, mesmo sendo bens doados pela Coroa, como a fazenda de Achada Falcão. Exigia ainda do pretendente cinquenta mil reis e doze mil reis, respetivamente para a doação de bens e direitos. Além disso, os proprietários teriam de pagar cinco mil reis pela carta de instituição da doação, como também quarenta mil reis de selo para aforamentos dos bens nacionais. Para cada arrendamento feito deveriam ser cobrados quarenta reis de selo. A leitura dessa fonte permite observar que os rendeiros exigiram os mesmos direitos políticos e garantias legais que os morgados. Não por acaso, exigiram contratos escritos para que todos pudessem recorrer ao poder judicial, como forma de reivindicar as condições de arrendamento das terras. As mesmas atestam ainda que almejavam também repor a justiça social, uma vez que apenas meia dúzia de homens detinha a posse legal das terras, indevidamente concedidas pelas câmaras municipais.

As diversas solicitações ainda nos possibilitam sustentar que as reivindicações por rendas fixas e justas, mediante um contrato escrito de arrendamento, também abrangiam outros morgados,

49 AHN, $S G G$ - Correspondências diversas recebidas das diferentes Administrações de Concelhos da Província de Cabo Verde (1841-1926). Cx. 122, doc. 1088, de 24 de março de 1841. 
tais como: Luiz Freire e Francisco dos Reis Borges. Os documentos comprovam não só que a revolta se registou dentro do morgadio de Achada Falcão, como também que contou com a participação de rendeiros dos morgadios mais próximos. A leitura dessas fontes permite compreender que se tratava de reivindicações coletivas tanto contra as opressões quanto pela posse das terras cultivadas. Além disso, permite compreender os acontecimentos também pela versão dos dominados, que se sujeitam ao poder dos dominantes.

Entretanto, atestam a convicção que os morgados não tinham a posse legal sobre as terras cultivadas, pois pertenciam às câmaras municipais. A análise cuidadosa desses documentos permite compreender que esses trabalhadores rurais reivindicavam não só por melhores condições de trabalho, como também por livre acesso a terra. Ainda atesta que as rendas fixas só poderiam ser garantidas, caso houvesse, como determinava a lei vigente, um contrato escrito, com os proprietários de terras, devidamente registado em cartório e reconhecido pelas câmaras municipais. Destacam a necessidade do reconhecimento de direitos individuais, para a própria segurança do inquilino $^{50} \mathrm{em}$ face das imposições ilegais dos seus morgados. Atestam que os liberais exaltados continuaram a exortar esses trabalhadores rurais a contestarem a ordem política vigente, exigindo que os direitos políticos fossem extensivos a todos os segmentos políticos. Além disso, demonstram de que forma os seus interesses eram opostos aos interesses desses políticos, ávidos por cargos públicos dentro dos concelhos.

(...) Levão ao Conhecimento de V. a Mag. a o seguinte he espresso na Carta de Lei Programatica, de 25 de Junho, do anno de 20 de Dezembro do anno de 1837 \# dada pellas cortes gerais e estordinarias da nação Portugueza com principio de 1838 dis que todos os Alvarás para a anexação de Morgados sendo o Capital quatro contos de Reis pagara sincoenta mil Reis se sello de quatro contos a oito contos sasenta mil reis de sello de oito contos a doze Contos satenta Mill reis de sello, de doze Contos a sima oitenta mil reis de sello e todos os Arrendamentos quarenta reis se sello, Contos de Capellos de a Duação de bens da Coroa ou outros bens nacionais pagara sello dês mil reis decretos desacrificação devidos pagara sello, sincoenta mil reis Alvarás ou Sortarios para se Manter na posse de bens nassionais pagara se sello doze mil reis Carta de Instituição de a Duação [Doação] sinco mil reis, Afforamentos Renovações de hipotecas e Subemphitenticações de bens nacionais pagara quatro mil reis de sello, e todos os Arrendamentos que se fizerem pagara Cada hum quarenta reis de sello porque Aqui nada disto há sendo tudo em projuizo [prejuízo] grave Contra a Fazenda nassional e Contra os supp.tes e bem Publico poriço S. a V.a Mag.e se Digne Mandar que todos os Morgados que Arrendao terras nesta Ilha de Santiago no termo

50 Pessoa que residia numa casa ou terra arrendada. 
de 15 dias Aprezentamm neste tribunal os tombos de seus Morgados para serem vistos se estão na forma da Lei (...). ${ }^{51}$

Contudo, na ilha de Santiago, esta lei não era posta em prática, o que acarretava grande prejuízo não só para a fazenda nacional, como também para o bem público. Os referidos trabalhadores pediram que se averiguasse se todos os morgados estavam cumprindo o decreto de 13 de agosto de 1832 e a carta de lei de 20 de dezembro de 1837. Exigiram também, com base os incisos 29, 30 e 33 da portaria de 24 de abril de 1837, que regulamentava o aforamento das terras incultas, que as suas reivindicações fossem atendidas pelo governo geral de Cabo Verde. Ainda sustentaram que para que as terras fossem aproveitadas na sua totalidade, segundo o inciso 33 do mesmo decreto, era preciso que as rendas cobradas pelo arrendamento das terras fossem fixas. ${ }^{52}$ Os documentos comprovam ainda que os mesmos reivindicavam mais garantias legais, tendo os morgados a obrigação de conceder as terras em arrendamento por um valor fixo. Por meio desta iniciativa administrativa, pretendiam impedir que os morgados, como estratégia política continuassem a aumentar excessivamente as rendas das terras. Os pedidos dirigidos ao governo geral atestam que eles não deveriam mais pagar as rendas e os impostos sem que obtivessem o livre acesso a terra. A análise dessa documentação é de extrema importância para a compreensão do cotidiano das explorações, tendo em vista que se revestiam de únicos instrumentos legais, postos à disposição desses trabalhadores rurais, tanto para reivindicar direitos quanto para solicitações diversas. Além disso, são fontes preciosas para a compreensão dos privilégios econômicos que esses poderosos gozavam.

As reclamações escritas individualmente demonstram que os mesmos inicialmente acreditavam nas apelações dirigidas ao governo geral. Porém, não obtendo resposta às suas reivindicações viram na revolta a única forma eficaz para subverter o monopólio políticoeconômico vigente. As diversas solicitações constantes desta série atestam que a revolta também revestia de um grande significado para as mobilizações políticas, sobretudo na reivindicação pela participação no ato eleitoral, da qual estavam inteiramente excluídos.

Por outro lado, são importantes fontes de informações não só sobre as rendas familiares, como também acerca dos critérios adotados no próprio arrendamento das terras. Esta série

51 AHN, $S G G$ - Correspondências diversas recebidas das diferentes Administrações de Concelhos da Província de Cabo Verde (1841-1926). Cx. 122, doc. 1088, de 24 de março de 1841.

$52 \mathrm{AHN}, S G G$, Correspondências expedidas às diversas autoridades da Província (1837/maio/29-1838/julho/19). Cópias manuscritas. Livro 121, de 24 de abril de 1837. 
documental atesta que, por vezes, os rendeiros pagavam uma renda que variava de 1200 a 7400 reis aos seus morgados pelo usufruto das terras. Demonstram que tais iniciativas econômicas levam crer que os morgados fixavam o preço dos arrendamentos como forma de condicionar o livre acesso às terras por parte dos seus rendeiros. Atestam ainda que quanto maior fosse à colheita obtida pelo rendeiro maior era a renda fixada pelo morgado. Neles estão expressas profundas revoltas, pelo fato dos morgados utilizarem o aumento das rendas a fim de evitar que os rendeiros pudessem aceder à condição de cidadãos.

Se dantes, as reivindicações eram dirigidas de uma forma individual ao governo geral, com as mobilizações políticas passam a agregar uma pluralidade de reivindicações. Os mesmos ainda atestam que as elites políticas locais fizeram crer aos trabalhadores rurais que deveriam exigir do proprietário um contrato escrito, como garantia dos seus direitos. Neste caso, seis dos mais influentes denunciaram os desmandos, visto que nunca foi celebrado um contrato escrito com os mesmos. Essa série documental possibilita articular a disputa partidária às estratégias de lutas políticas, dentre as quais, a subversão ao regime de monopólio político-econômico vigente. A estrutura documental acaba por refletir a natureza desas disputas políticas, tendo em vista que os mesmos representavam os únicos instrumentos que tinham ao seu dispor para contestar os abusos de poder.

As próprias reivindicações, ao denunciarem o descumprimento, por parte dos morgados, das leis vigentes sobre o arrendamento das terras, comprovam que os trabalhadores rurais não eram tidos como cidadãos, sem quaisquer direitos para a ordem política vigente. A análise dessa documentação permite sustentar que a revolta é resultado das diferentes lutas e reivindicações pela integração do rendeiro na nova ordem política, por meio da subversão às normas vigentes. Além disso, atesta que osmesmos aspiravam instaurar uma nova sociedade, assente na justiça, igualdade e liberdade. Para tal, deveriam reivindicar o livre acesso a terra, até ali negado pelo governo. Os protestos apresentados comprovam que os mesmos apresentavam-se como principal força resistência a extrema da terra.

Esta série documental atesta ainda que a eclosão da revolta estava diretamente articulada às práticas de injustiça por parte desses poderosos, que detinham o monopólio da maior parte das terras da ilha. Ali está expresso o dilema da escassez de terras, da oralidade dos contratos, das extorsões registadas na venda das colheitas aos morgados. Destacam ainda o fato da manipulação dos tribunais locais estarem diretamente relacionadas a um conjunto de estratégias políticas 
utilizadas para inviabilizar as aspirações dos rendeiros em poderem exercer os seus direitos políticos. Permite ainda sustentar que a revolta de Achada Falcão (1841) deve ser compreendida dentro de um conjunto de reinvindicações políticas apresentadas pelos rendeiros, dentre as quais, cabe destacar: o livre acesso a terra e o direito de votar em candidatos à cargos públicos. Ressalta ainda que a revolta fazia parte de estratégias políticas colocadas em prática para pressionar o governo geral de Cabo Verde e os respectivos proprietários de terrras a concederem maior liberdade de acesso a terra, até o momento negado a esses trabalhadores.

Os documentos que fazem parte dessa série destacam o fato das diversas legislações decretadas pelo governo local limitar-se a garantir aos morgados a posse das terras. Além disso, permitem-nos compreender que, além de uma simples reivindição contra o a extrema concentração de terras, a revolta representava uma oportunidade para contestar também o monopólio político vigente.

Assim, as diversas reivindicações, ao retomarem a legislação fundiária vigente em Cabo Verde, colocam em evidência várias estratégias de mobilização. Dentre essas estratégias realçadas cabe destacar a reinterpretação da mesma dentro dos princípios separatistas do referido partido. Possibilita ainda compreender em que circunstância e para que finalidade os rendeiros e a respectiva liderança local utilizavam essas diversas legislações sobre a terra em Cabo Verde. Também permite analisar de que forma os mesmos utilizavam a ordem dominante, ressignificando o seu sentido para o grupo.

A análise dessa série documental também permite compreender que a eclosão da violência tinha por base exigências legais. As solicitações dirigidas ao governo geral atestam não só a grande exploração, como também a conivência das autoridades locais, a quem cabia resguardar os interesses da Coroa portuguesa. Segundo consta, esses trabalhadores tencionavam, por meio dessa exposição ao governo geral, defender não só o seu direito a um contrato escrito, quanto à obrigação que a câmara municipal de Santa Catarina tinha em cobrar dos proprietários o foro das terras, com base no $\operatorname{art}^{\circ} 3^{\circ}$, do decreto de 13 de agosto de 1832. Acreditavam estar defendendo o direito de se rebelar contra as medidas opressivas, suportadas pelo referido decreto, que regulamentava a concessão de aforamentos das terras em Cabo Verde. Com base na constituição de 1838 passaram a exigir o cumprimento das leis em vigor tanto em relação aos impostos devidos quanto à legalidade dos atos praticados. 
É preciso ainda salientar que os pedidos individuais dos rendeiros só apareceram, enquanto ação planejada e coletiva, com as mobilizações políticas em torno do referido partido. Em primeiro lugar, possibilitam compreender como a liderança local compreendeu as diversas legislações sobre a terra em Cabo Verde. Tendo em atenção que os discursos comportam também práticas e estratégias de ação, os mesmos atestam que as mobilizações deviam, em parte, à crença que estariam agindo com base na legalidade. Em segundo lugar, destacam o fato da liderança local procurar fazer crer que a subversão à ordem sócio-política seriam os únicos instrumentos para contrapôr às injustiças reinantes. Além disso, as exposições atestam que para eles o fato dos poderosos não pagar os impostos devidos à Coroa portuguesa, seria relevante para a revogação do direito de posse das terras. Em terceiro lugar, essas microresistências enunciadas nos documentos atestam que tinham não só consciência da extrema exploração na qual estavam sujeitos, como também da profunda desigualdade da posse das terras.

De outro ponto de vista, sustentam que a existência de morgadios era incompatível com o regime constitucional, que proibia qualquer privilégio por nascimento. Segundo as correspondências expedidas ao Ministério da Marinha e Ultramar, as mobilizações políticas não só fez aumentar o número dos revoltosos, como também começaram a incorporar escravos descontentes. O fato da revolta agregar todos os trabalhadores rurais livres ou na condição escrava, atesta que a exploração dos rendeiros equiparava-se a dos escravos, tendo em vista que ambos viviam na dependência econômica dos seus morgados. Além disso, atestam que os mesmos não gozavam de nenhum direito político, principalmente o direito de votar e ser votado para cargos políticos dentro dos concelhos. Além disso, a análise dessa documentação é de suma importância para a compreensão do regime de trabalho vigente. Esses trabalhadores, apesar de livres, na prática continuavam sendo escravos do regime político vigente, que apenas legitimava e reconhecia o poderio desses grandes comerciantes. ${ }^{53}$

Além do retratar o cotidiano das mobilizações, as formas em que se revestiam as explorações, as correspondências dirigidas às autoridades da ilha de Santiago atestam o cotidiano das fomes. Numa exposição da câmara de Santa Catarina, cujas reivindicações foram prontamente atendidas pela Coroa por meio da doação de um terreno de nome Castelo, foi arrolada a falta de meios para o cumprimento dos encargos administrativos, uma vez que todas as verbas foram direcionadas para combater a fome. As referidas fontes apresentam o povo mergulhado numa

53 AHN, $S G G$, Correspondências expedidas ao Ministério da Marinha e Ultramar (1841/janeiro/021841/dezembro/31). Cópias manuscritas. Livro nº 96, de 5 de fevereiro de 1841. 
profunda miséria, sem poder pagar os impostos ao município, fazendo com que se recorresse à venda de bens públicos em poder das câmaras municipais para satisfazer as despesas administrativas.

Tendo subido á Minha Presença ${ }^{54}$ a reperesentação da Câmara Municipal do Conselho de Santa Catharina de Cabo Verde, na qual ponderava a absolucta falta de meios para satisfazer aos encargos Municipaés, e (...) pela grande pobreza aquelle Povo, que se achava reduzido a extrema mizeria em conseqüência do terrível flegello da fome, que por mais de trez annos aflora aquella Província, e que de modo algum podia satisfazer as indispensáveis despezas do Município, se Eu lhe não fizesse Mercê de uma terra (...) denominado $=$ Castello $=$ pertencente á Fazenda Nacional. ${ }^{55}$

Os próprios cofres públicos tiveram que suportar as dívidas contraídas para compra de mantimentos, a fim de serem distribuídos aos famintos. Devido à escassez de dinheiro decorrente da fome dos anos de 1831 e 1833, o governo geral de Cabo Verde pediu, por meio de um ofício dirigido ao presidente da câmara municipal de Santa Catarina, datado de 20 de janeiro de 1836, para que a câmara convencesse os proprietários de terras a receberem as rendas em gêneros, quando os rendeiros não pudessem pagar em moedas. Porém, os mesmos recusaram receber as rendas em colheitas devido às vantagens econômicas que poderiam tirar das épocas de estiagens. Como consequência, proibiu todo o envio de cereais e legumes para fora das ilhas, medida essa que perdurou até $1845^{56}$.

Essa perspectiva foi reforçada por outro depoimento que além de denunciar o desprezo por parte da Coroa, confirma a existência de beneficios concedidos a alguns dos escolhidos dela. A análise dessa documentação permite compreender a displicência das autoridades locais diante da miséria e da indigência do povo. Delegavam esta responsabilidade à população, sendo que muitos indivíduos vendiam panos de seda nos portos ou mesmo terras por pequenas quantidades de arroz e de milho ${ }^{57}$.

Também denunciam a grande concentração de terras por ocasião dessas fomes. Atestam que os grandes proprietários, com a proibição da venda de bens de raiz, adquiriam as terras dos

54 Pela Rainha, Antonio Manoel Lopes Vieira de Castro.

55 AHN, $S G G$ - Portaria recebidas da Repartição do Ultramar do Ministério da Marinha (janeiro-dezembro/1837). Originais e Cópias manuscritas. Cx. 290, de 12 de janeiro de 1837.

56 Boletim Oficial do governo geral de Cabo Verde, $\mathrm{n}^{\mathrm{o}}$ 109, de 4 de outubro de 1845, p. 433-434.

57 Boletim Oficial do governo geral de Cabo Verde, $\mathrm{n}^{\circ}$ 119, de 27 de dezembro de 1845, p. 480. 
pequenos proprietários por preços irrisórios. Denotam ainda que a Coroa estava preocupada com os inconvenientes gerados pela troca de bens de raiz por gado, sem que a prefeitura pudesse interferir. Uma possível fiscalização mais aprofundada só seria possível só com o passar da fome, devido à insuficiência de funcionários. As denúncias se relacionavam com o aumento exorbitante do preço sobre a carne vendida, superior a trinta reis sob autorização das câmaras municipais. Tais medidas administrativas favoreciam o comércio monopolizado pelos morgados, devido, em parte, aos interesses econômicos dos morgados. Além disso, atestam que as autoridades locais aplicavam as diversas leis fundiárias, segundo os interesses dos proprietários de terras.

(...) Respondendo, o que entendo, sou a dizer a V. Ex. ${ }^{\text {a: }}$ que naõ acho illegalidade alguma, em que se facão trocas de propriedade de raiz por gados: se os donnos destes escedem o justo valor, estimando-os em mais, do que elles realmente válhaõ, e dando as propriedades menos valor do justo, para esse abuzo naõ acho remedio, que o privinamos, há remedio, que o desfaça, e hé, o que estabellece a Ordenação L. ${ }^{\circ}=4^{\circ}=\mathrm{N}^{\circ} .13(\ldots) .{ }^{58}$

Essas fontes documentais também permitem compreender a situação socioeconômica em que os rendeiros estavam inseridos. A pobreza era tão extrema que o prefeito de Cabo Verde, Manoel Antonio Martins, reiterou que o povo, despojado de bens e com lágrimas nos olhos, mendingavão esmolas à porta dos mesmos predios, que dantes os pertenciam. Descrevem ainda a dimensão do monopólio da terra, bem como a manipulação do poder judicial por parte dos $\operatorname{poderosos}^{59}$.

Ainda realça o grande poderio político dos morgados, preponderante na distribuição das terras. Registram também os descontentamentos dos pobres rendeiros diante da conivência das autoridades administrativas. Gregório Freire de Andrade, Marcelino Rezende e Antonio de Brito Lago perseguiam todos os seus opositores, por vezes, retirando-lhe a posse sobre as terras. Por meio o requerimento dirigido ao provedor, de 19 de novembro de 1831, Francisco Rodrigues, morador em Cham Branco, São Domingos (interior da ilha de Santiago), reivindicou a posse de umas terras em João d'Elvas, freguesia de Nossa Senhora da Luz, pertencente à Santa Casa da Misericórdia. No mesmo documento exigiu que o provedor mandasse lavrar a escritura de aforamento das ditas

58 AHN, $S G G$, Requerimentos (1832). Originais manuscritos. Cx. 39, doc. de 6 de setembro de 1832.

59 AHN, $S G G$, Ofícios expedidos ao Ministério e Secretaria de Estado da Marinha e Ultramar (1830/abr/021836/jan/13). Cópias manuscritos. Liv. 520, f. 171. 
terras, ficando obrigado a pagar anualmente laudémio. ${ }^{60}$ Por despacho, o referido provedor determinou que o juiz da referida instituição religiosa mandasse proceder a uma investigação. A solicitação foi verificada pelo reverendo padre vigário da freguesia, Gregório Freire de Andrade, o qual remeteu as informações ao requerente. Apesar de saber que as terras pertenciam à referida instituição, o reverendo reiterou que dirigiu um protesto, pleiteando estar na posse das referidas terras. Por sua vez, o requerente reivindicou a posse das terras, tendo em vista que as mesmas terras pertenciam à Santa Casa da Misericórdia e que, de forma ilegal, tinha em seu poder. Também considerou o pagamento de rendas ilegais, uma vez que as terras foram usurpadas ${ }^{61}$.

Os documentos registam também as disputas políticas, bem como as diversas denúncias contra o regime de exploração no arquipélago. Em 13 de janeiro de 1834, Marcelino Rezende Costa, ${ }^{62}$ escrivão e deputado da Junta da Administração e Arrecadação da Fazenda Pública, por meio de um ofício dirigido à rainha Dona Maria II, acusou o contratador da urzela, Manoel Antonio Martins, de praticar vários desmandos, dentre os quais destacamos: obrigar homens forros (rendeiros) a trabalhar nos domingos e dias santos, o que feria os preceitos da igreja; de no momento do pagamento dos insignificantes salários com roupas, os rendeiros, além de serem ameaçados, insultados e presos. As vítimas, face aos abusos do referido administrador, que pagava pela urzela quando quisesse, endereçaram protestos ao governador geral. Essas fontes revelam que, por vezes, tomava cavalos, vacas e burros dos rendeiros para vender aos navios estrangeiros que passam pela ilha de Boa Vista, pagando, posteriormente, o preço que quisesse. Revelam ainda que, apesar das inúmeras reclamações junto à câmara municipal, nenhuma iniciativa foi tomada contra 0 referido administrador que era também coronel de milícias. ${ }^{63}$ Atestam a oposição que os liberais exaltados fizeram contra a extrema exploração que os homens livres. Além disso, ressaltam o fato dos rendeiros fazerem uso de determinadas datas para apresentar os seus descontentamentos face ao regime político vigente, com especial realce para treze de janeiro.

60 Laudémio é a compensação devida ao senhorio direto, por não usar o direito de preferência quanto o enfiteuta aliena onerosamente o imóvel foreiro. Em outras palavras, trata-se de uma renda que a Coroa portuguesa tinha direito a receber quando o ocupante ou o foreiro dentro da sua propriedade transferisse os direitos de ocupação ou de foro a outrem.

$61 \mathrm{AHN}, S G G$, Requerimentos (1831). Originais manuscritos. Cx. 037

62 Vice-cônsul da França na ilha de Santiago - AHN, $S G G$, Requerimentos (1827). Originais manuscritos. Cx. 40. Por envolvimento na Inconfidência Mineira foi degredado, em conjunto com o pai João de Rezende Costa, inicialmente para Guiné Bissau e, posteriormente, transferido para a ilha de Santiago, onde veio a falecer. O autor Rosalvo Gonçalves Pinto, na sua obra "Os inconfidentes José de Rezende Costa (pai e filho) e o arraial da Lage", chega mesmo a defender que os dois inconfidentes permaneceram na ilha de Santiago, onde o pai veio a falecer em 1798. Cf. PINTO, Rosalvo Gonçalves. Os inconfidentes José de Resende Costa (pai e filho) e o arraial da Laje. Brasília: Senado Federal/Subsecretaria de Edições Técnicas, 1992.

63 AHN, SGG, Portarias e estudos do Tesouro Público (fev-set/1835). Originais e cópias manuscritos. Cx. 285. 
A série dos requerimentos atesta a ascenção e o poderio de uma elite política nativa, apelidada de negros terroristas, que se dedicava a resistir aos abusos cometidos pelos grandes proprietários rurais. Atesta ainda que foram promovidos para cargos públicos tanto degredados quanto mulatos bébados, desprezados pelos anteriores governos. Também destaca o fato desses opositores lancarem mão de devassas, calúnias, roubos de propriedade, como também na promoção de contrabandos.

Segundo uma dessas solicitações assinada por Marcelino Rezende, o contratador aproveitava para estorquir dos miseráveis algum dinheiro, uma vez que o arroz vendido, na maioria das vezes, continha lixos e terra. O contratador pagava também com penico, pratos, canecas, copos, talheres, papel, cachimbos, agulhas, alfinetes, com o único propósito de não pagar em dinheiro. Tal medida fazia parte da estratégia para impedir que os urzeleiros comprassem o milho mais barato. Destaca o fato dos urzeleiros sofrerem grande prejuízo com a venda da urzela. Se um alqueire de milho era vendido a duas patacas, a urzela era comprada um alqueire mais barato. Os referidos documentos atestam ainda que Marcellino Rezende da Costa intitulou-se protetor dos mais fracos, denunciando os abusos decorrentes do monopólio político-econômico, responsável, em parte, pela miserabilidade do povo, como também representava a principal barreira para a posse das terras que cultivavam.

É possível assim concluir que os requerimentos se revestiam dos principais instrumentos legais usados pelos rendeiros para contestar as injustiças sociais, o monopólio da terra e do poder político e o regime de exploração das mesmas. Se na vigência do governo geral, os mesmos eram dirigidos às administrações locais que, por sua vez, as encaminhavam para o governo geral. Com a prefeitura de Cabo Verde e Costa da Guiné, os mesmos passam a ser dirigidos diretamente ao prefeito. Cabem ainda reiterar que a releitura dessas fontes possibilita a compreensão do cotidiano de extrema exploração desse segmento social, como também os argumentos legais que estes utilizavam para contrapor aos desmandos dos morgados.

\section{REFERÊNCIAS BIBLIOGRÁFICAS}

\section{Obras gerais}

AMARAL, Ilídio do, Santiago de Cabo Verde: A Terra e os Homens. Lisboa: Memórias da Junta de Investigação do Ultramar, n. 18, 1964.

ANDRADE, Elisa Silva. As Ilhas de Cabo Verde: da Descoberta à Independência Nacional (1460-1975). Paris: Éditions L'Harmattan, 1996, p. 115. 
BARCELLOS, Christianno José Senna. Subsidios para a História de Cabo Verde e Guiné. Lisboa, 1899-1911, parte IV, v. I.

BEARMAN, David A. \& LYTLE, Richard H.. The power of the principle of provenance. In: JIMERSON, Randall C., ed.. American archival Studies: readings on theory and pratice. Chicago: The Society of American Archivists, 2000, p. 345-360.

BOURDIEU, Pierre. O poder simbólico. $11^{\mathrm{a}}$ ed., Rio de Janeiro: Bertrand Brasil, 2007 . [1 $1^{\mathrm{a}}$ ed. 1989].

CARREIRA, António. Cabo Verde: Formação e Extinção de uma sociedade escravocrata (1460-1878). Porto: Imprensa portuguesa, 1972.

CHESNEAUX, Jean. Devemos fazer tábula rasa do passado? (sobre a história e os historiadores). São Paulo: Ática, 1995 (Série Fundamentos, 109).

DURANTI, Luciana. “La diplomática: disciplina fornativa y método de investigación". Diplomática: usos nuevos para una antigua ciencia. Traducción de Manuel Vázquez. Carmona: S\&C Ediciones, p. 143-166, 1996.

FLORESCANO, Enrique. "De la memoria del poder a la historia como explicación". In: PEREYRA, Carlos et. al. Historia, para quê?. 17ª ed., México: Siglo Veintiuno Editores, 1998. [1 $1^{\text {a }}$ Ed. 1980], p. 91-128.

FURTADO, Cláudio Alves. Transformação das Estruturas Agrárias numa Sociedade em mudança - Santiago Cabo Verde. 357 f. Dissertação (Mestrado em Sociologia) - Faculdade de Filosofia, Letras e Ciências Humanas, Universidade de São Paulo. São Paulo, 1988.

GONZÁLEZ, Luis. "De la multiple utilización de la Historia". In: PEREYRA, Carlos et. al. Historia, para quê?. 17ª ed., México: Siglo Veintiuno Editores, 1998. [1ª Ed. 1980], p. 53-74.

PINTO, Rosalvo Gonçalves. Os inconfidentes José de Resende Costa (pai e filho) e o arraial da Laje. Brasília: Senado Federal/Subsecretaria de Edições Técnicas, 1992.

POLLAK, Michael. "Memória e identidade social”. In: Estudos Históricos. Rio de Janeiro, vol. 5, n. 10, 1992, p. 200-212.

SCHWARTZ, Joan M. e COOK, Terry. Archives, records, and power: the making of modern memory. Archival Science, Dordrecht, v. 2, n. 1-2, p. 1-19, 2002.

SILVA, António Leão Correia e. "A Sociedade Agrária: Gente das Águas (Senhores, Escravos e Forros)". In: ALBUQUERQUE, Luís de e SANTOS, Maria Emília Madeira (Coord.). História Geral de Cabo Verde. Lisboa: Centro de Estudos de História e Cartografia Antiga, Instituto de Investigação Científica Tropical; Praia: Instituto Nacional da Cultura de Cabo Verde, 1995, v. II, p. 275-359.

VILLORO, Luis. "El sentido de la Historia". In: In: PEREYRA, Carlos et. al. Historia, para quê?.

$17^{a}$ ed., México: Siglo Veintiuno Editores, 1998. [1 ${ }^{\text {a }}$ Ed. 1980], p. 33-52.

\section{Fontes manuscritas}

1 Arquivo Histórico Nacional de Cabo Verde (AHN), cidade da Praia

Caixas: 27, 27 (M), 28, 29, 31, 33, 37, 39, 40, 122, 285, 290

Livros: 96, 106, 121, 520. 
2 Arquivo Histórico Ultramarino (AHU), Lisboa Caixas: 72

3 Arquivo Histórico Militar (AHM), Lisboa

Autos da Devassa a que se procedeu sobre o levantamento dos Habitantes da Ribeira do Engenho (1822-1823). $2^{\mathrm{a}}$ Divisão, $3^{\mathrm{a}}$ Secção, Cx. 2, Proc. 8.

3. Periódicos

Boletim Oficial do governo geral de Cabo Verde, $n^{\circ}$ 109, de 4 de outubro de 1845.

Boletim Oficial do governo geral de Cabo Verde, $n^{\circ} 119$, de 27 de dezembro de 1845. 


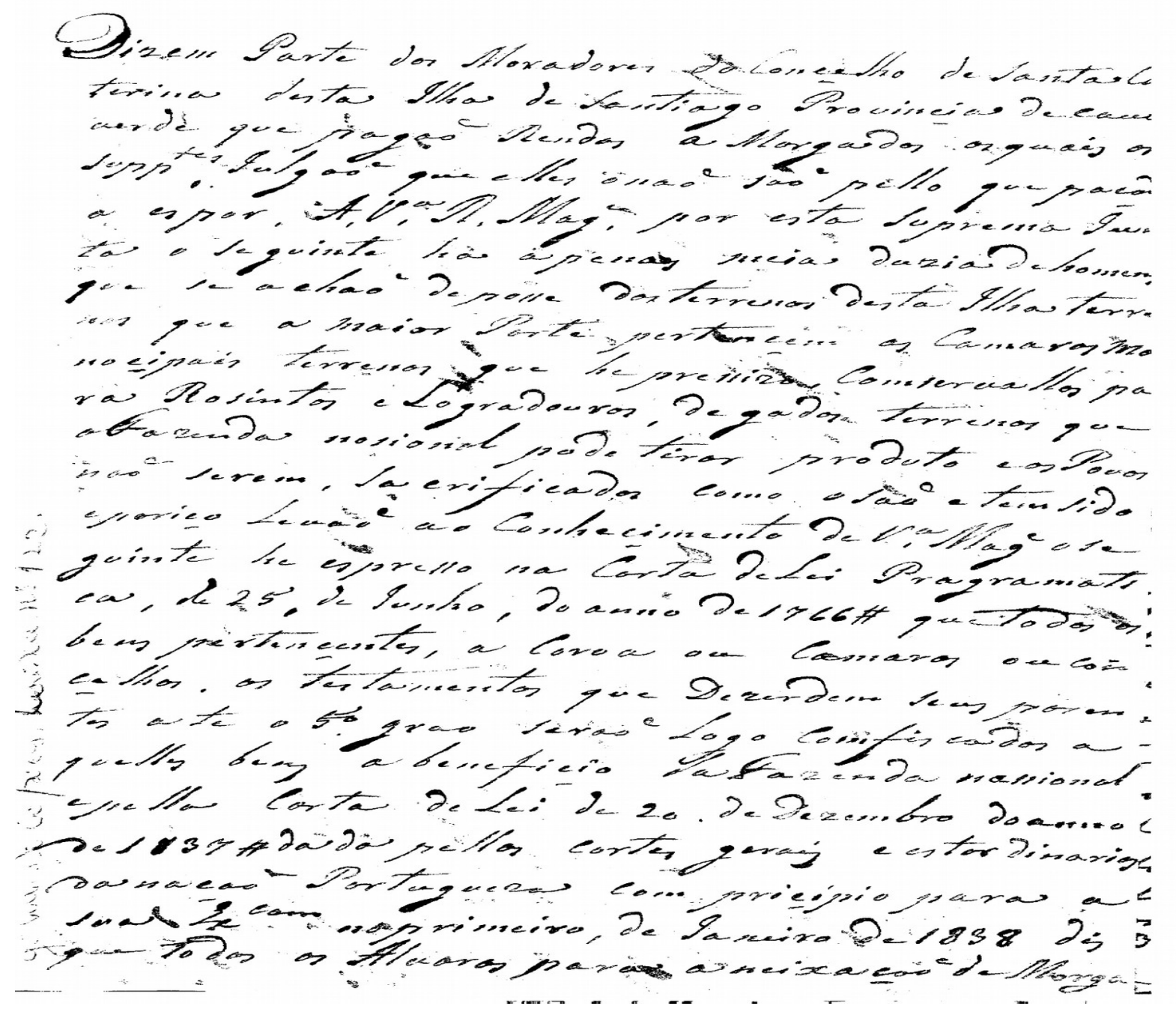




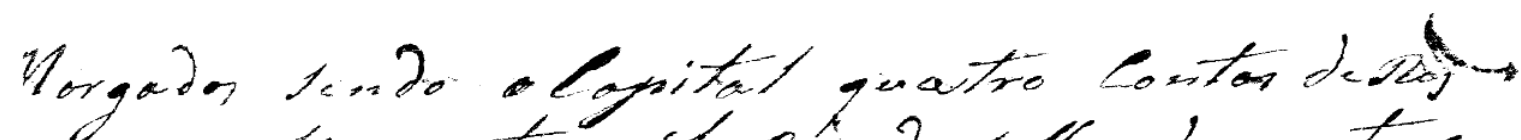

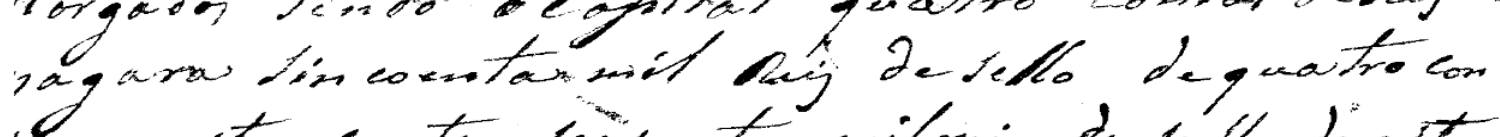
s: a oito costor laventa milruj de sello deorto

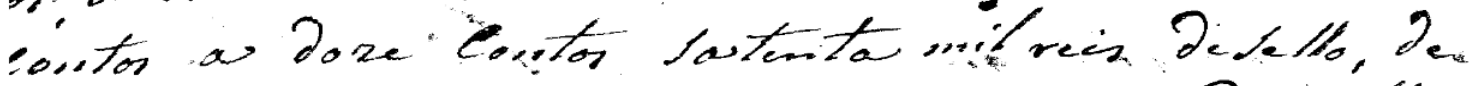

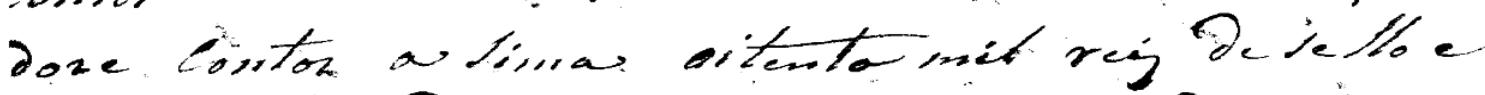

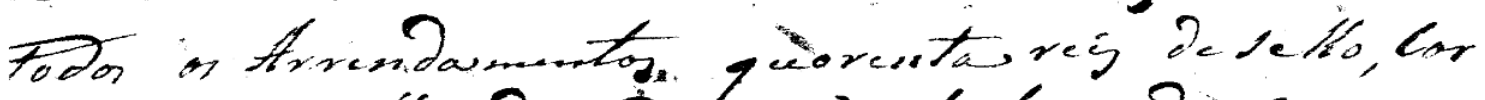

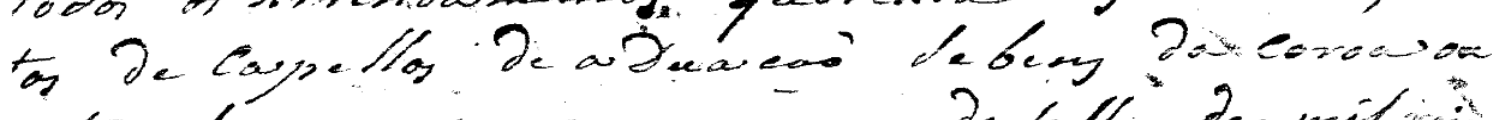

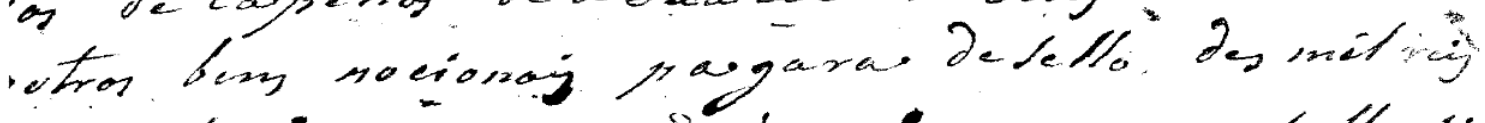

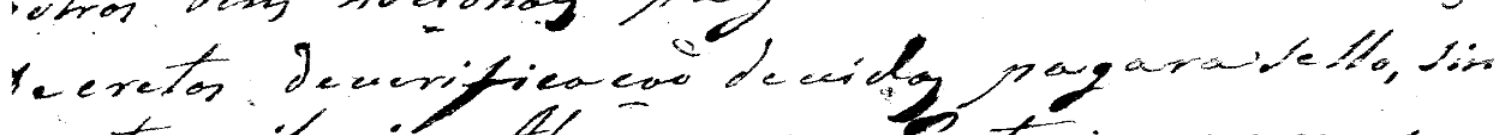
ocrita nit rej fteara oce Sortarias parare Hoster wapele debary parionay pazara de lello

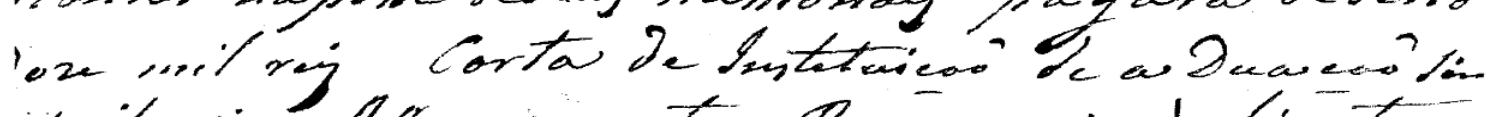
ofmil ruy, Afforaincertor Menaceacoj de hiporecey

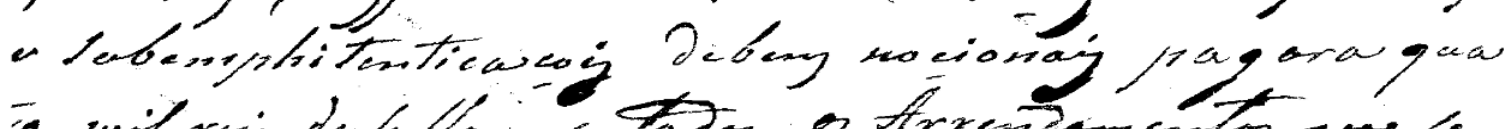

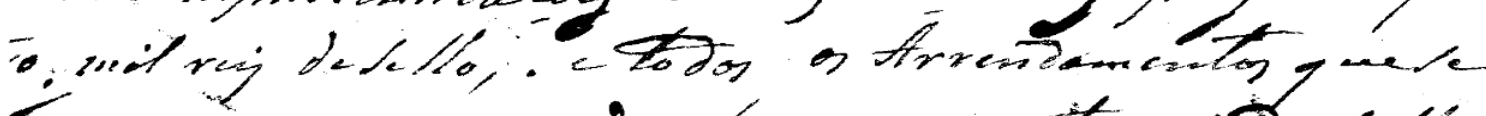

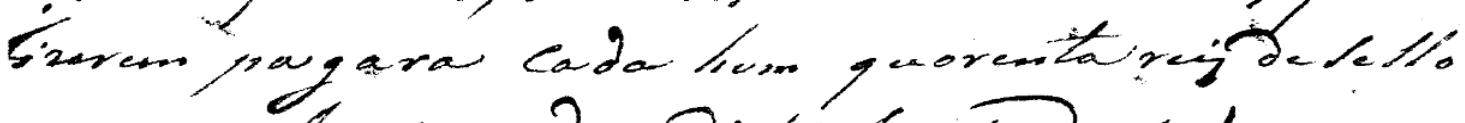
porgue Hyar, mada Dito ha tando tendo anpro

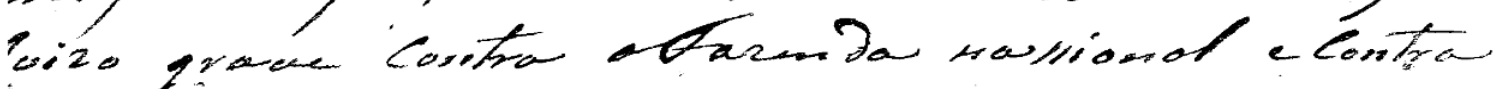

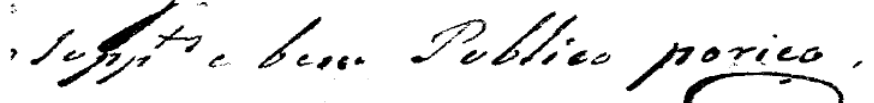

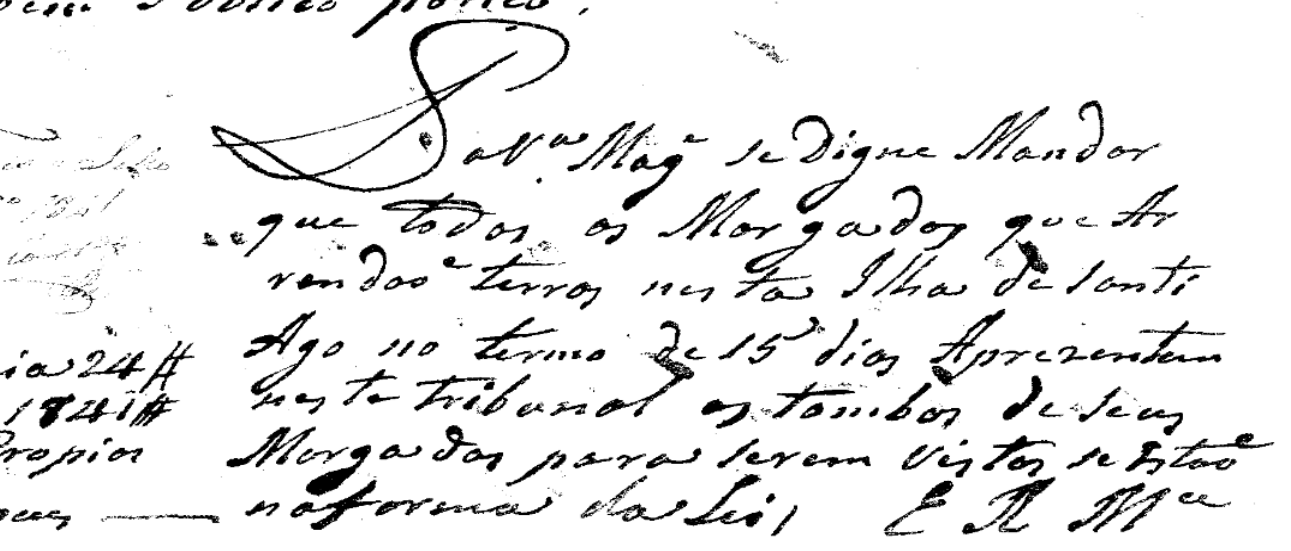

Fonte: AHN, SGG, Correspondências diversas recebidas das diferentes Administrações de Concelhos da Província de Cabo Verde (1841-1926). Cx. 122, doc. 1088, de 24 de março de 1841. 